\title{
De Nederlandse privaatrechtsleer in dramatisch perspectief
}

Citation for published version (APA):

Roos, N. H. M. (1987). De Nederlandse privaatrechtsleer in dramatisch perspectief. Wolters-Noordhoff. https://doi.org/10.26481/spe.19871127nr

Document status and date:

Published: 27/11/1987

DOI:

$10.26481 / \mathrm{spe} .19871127 \mathrm{nr}$

Document Version:

Publisher's PDF, also known as Version of record

\section{Please check the document version of this publication:}

- A submitted manuscript is the version of the article upon submission and before peer-review. There can be important differences between the submitted version and the official published version of record.

People interested in the research are advised to contact the author for the final version of the publication, or visit the DOI to the publisher's website.

- The final author version and the galley proof are versions of the publication after peer review.

- The final published version features the final layout of the paper including the volume, issue and page numbers.

Link to publication

\footnotetext{
General rights rights.

- You may freely distribute the URL identifying the publication in the public portal. please follow below link for the End User Agreement:

www.umlib.nl/taverne-license

Take down policy

If you believe that this document breaches copyright please contact us at:

repository@maastrichtuniversity.nl

providing details and we will investigate your claim.
}

Copyright and moral rights for the publications made accessible in the public portal are retained by the authors and/or other copyright owners and it is a condition of accessing publications that users recognise and abide by the legal requirements associated with these

- Users may download and print one copy of any publication from the public portal for the purpose of private study or research.

- You may not further distribute the material or use it for any profit-making activity or commercial gain

If the publication is distributed under the terms of Article $25 \mathrm{fa}$ of the Dutch Copyright Act, indicated by the "Taverne" license above, 
De Nederlandse privaatrechtsleer in dramatisch perspectief 



\section{N. Roos}

\section{De Nederlandse privaatrechtsleer in dramatisch perspectief}


De Nederlandse privaatrechisleer in dramatisch perspectief

\section{Rechtswetenschappelijke Reeks}

\section{Redactie}

Prof. mr. J.A. Ankum

Prof mr. J.F. Glastra van Loon

Mr. F.A.J. Gras secretaris

Prof. mr. A.J. Hoekema

Drs. E.A. Baerends

Dr. K.A. Soudijn

Reeds verschenen

De sociale werkellijkheid van het standaardcontract

Mr. F.A.J. Gras

Industrie, milien en wetgeving

Dr. M.V.C. Aalders

Regels en redelijkheid in de bijstandsverlening

R. Knegt

Regeltoepassing in de ambtelijke praktijk van

Hinderwet - en Bouwtoezichtafdeling

Dr. M.V.C. Aalders

Fraudeofficieren in de opsporing

Mr. H.G. wan de Bunt en Mr. J.H. Peek

Norm en Handeling

Prof. mr. J.F. Glastra van Loon

$\begin{array}{llllllllllll}0 & 1 & 2 & 3 & 4 & 5 & / & 91 & 90 & 89 & 88 & 87\end{array}$

Copyright (c) 1987 Wolters-Noordhoff bv Groningen, The Netherlands

Alle rechten voorbehouden. Niets uit deze uitgave mag worden verveelvoudigd, opgeslagen in een geautomatiseerd gegevensbestand, of openbaar gemaakt, in enige vorm of op enige wijze, hetzij elektronisch, mechanisch, door fotokopieën, opnamen, of op enige andere manier, zonder voorafgaande schriftelijke toestemming van de uitgever.

All rights reserved. No part of this publication may be reproduced, stored in a retrieval system, or transmitted in any form or by any means, electronic, mechanical, photocopying, recording or otherwise, without the prior writen permission of the publisher.

ISBN 9001762506 
DE NEDERLANDSE PRIVAATREOHTSUEER IN DRAMATISCH PERSPECTIEF

Rede gehouden op vrljdag 27 nowember 1987 ter gelegenthelld van de aanvaarding van het ambt van hoogleraar In de metajurldica an de jurldische facultelt wan de Rlljksuniversitelt Limburg door prof. mr. N.H.M. Roos. 
Introudsopove

1 Inlelding

2 Wat is metajur lallica?

3 De dlalectlek van heer- en knechtschap in het rectrt 6

4 Het Nleuw Eurger IIIk Wetboek a "unzeltgemalsses' verxchljusel 11

5 De echo van Von Savigny 16

6 Het ontstaan wan het NEW als een samenloop van vain omstandigheden 21

7 Meljers: miskend erkend genle 27

B De "petite histolre" van een grote controverse 32

9 Mellers en de (privaat)rechtsleer in de tweede helft van deze eeuw 42

10 De verhouding van wetgever en rechter 45

Noten $\quad 51$ 


\section{Inllelding.}

Deze openbare les bestaat uit dr le onderdelen. Ik zal erst verduldelljken wat ik onder metajurldica will verstaan. Daarna zal $k$, mede ter lllustratle van dle covatting de ontwlkkellng van de Nederlandse privaatrechtsler in deze als object van een metajur dische exercitle nemen. Deze zal mill tenslotte tot en staktstheoretische conclusle leiden, waaraan lik een woorstel tot verandering van ons polltileke stelsel zal verbinden.

Veel van wat $1 k$ hler zal beweren zal een nogal apodlctisch kam rakter dragen in verband met ruimtell Jke becerkingen. BlJ het voorberelden van deze openbare les is het werk mu weer eens fillnk ult: de hand gelopen (1). Mijn visie co de ontwlikkeling wan de Nederlandse (prlwaat)rechtsleer hoop ik over nlet te lange tljd in de worm wan een boek te publiceren. Dat sommlge van miljn beweringen in deze openbare les vooralsnog niet erg ulitvoerlg en stevlg onderbouwd zullen zljn, zal ongetwljfeld ergerlljk zlljn voor de critlcl, die zullen staan te trappelen van ongeduld om $\mathrm{mll}$ van katcen te dlenen. I $k$ zal mil namellJk, hoewel $i k$ op privatrechtel ljJk terreim weinlg deskundlg ben, nlet alleen maar in dle gewlyde leeuwekull begeven, maar $1 \mathrm{k}$ zal bovendlen, gek wan angst natuur $I I k_{n}$ cok nog "boer" roepen tegen de leeuwen, hooend dat mil het geluk van Danlel $6: 22-23$ beschoren zal zljn.

\section{Wat is metajur lalica?}

Bif de offlclele alanvaarding van het, woorzover mlJ bekend, enlge noogleraarsambt in de wereld dat de metalur ldica tot leeropdracht heeft, IIJkt het mIJ passend het een en ander te zeggen over wat ik onder dle geenszins nleuwe, maar tooh nlet zeer gebrulkelljke term wil verstaan. Ik versta die ultarukking in een rume en in een enge $z \ln$.

In de rulmere $z$ In is het een verzamelterm woor alle extern-lurldische persocteven op het recht, zodis bllwoorbeeld de rechtessoelologle, de rechtsgeschleden Is of de rechstheorlie. Met 'externJurldisch" bedoel $\mid k$, dat het er nlet om gaat om In prescr lptleve 


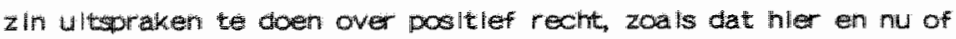
in de toekomst zou moeten gelden dan wel in het ver leden had behoren te gelden naar de geldingscriterla van dit positilewe recht zelf. BI) de hantering wan het onderscheld van externe en interne rechtsbeschouwing is het oppassen geblazen en wel om vier redenen.

In de ste plats moet het onderscheld nlet verward worden met thet al dan nlet ratlonele karakter van een Jurfldische beschouling. of een Interne beschouw ing rationeel karakter heeft, hangt af van de mate way in er zlch binnen een bepaald rechtssysteem in woldoende mate duldellike matstaven ter beoordelling van de aanvaardbaarheld wan ultworaken in dat systeem ontwlkkeld hebben. ook bly gebrek aan interne rationalltelt, kan een Interne rechtsbeschouwing ulteraard wel ratloneel zijn gemeten naar externe, dat wil zegigen nlet intern hanterbare criterla, zoals bljworbeeld crlterla van socilale of economische ratilonalltelt.

Een tweede reden om co te passen met het onderscheld lntern-extern is dat in intern gerlchte beschouwlingen over recht heel wat beweringen voorkomen dle ook naar externe maatstaven aanvaarchar zlJn. Dat de Hoge Raad in 1919 het arrest Llndebaum-Cohen 'onzorgvuldigheld In het maatschappelljk verkeer als rechtsgrond woor een actle tot schadevergoeding uit 1401 BW erkend heeft, is bljwoorbeeld zo'n ultsoraak. Meestal zal een dergelljke ultspraak in een intern betoog echter worden gebrulkt a is argument woor het felt dat de Hoge Raad dat ook In het Mller en nu voorllggende geval zou moeten doen en dan heeft ziJ andere strekking dan in een extern betoog. waar in het er bljvoorbeld om zou kunnen gaan te verk laren warom de Hoge Raad Julst toen is omgegaan (2).

Een derde reden om het onderscheld tussen externe en interne rechtsbeschouwing voorzlchtig te hanteren, is dat het nlet verward moet worden met het onderscheld desorlptief-prescrlptlef. Een intern betoog is wellswaar in laatste Instantle prescrlptlef gerlent, maar maakt, zoals gezegd, gebrulk van talloze ultsoraken, dle vanult zulver descrlptlef perspectlef volkomen aanvardbaar zouden zldn. Omgekeerd is het zeer wel mogelljk vamult extern perspectief prescriptlef betoog te nouden, namelljk varullt normatieve ultgangspunten waarwan de gelding nlet wordt gebaseerd op het posiltleve recht. 


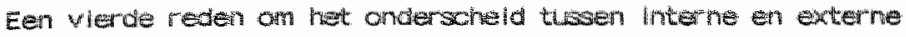
rechtsbeschouwing enlgsx ins te relativeren is gelegen in de vernouding tussen formele en materlele aspecten van het rech. Onder "formeel" versta IK hler het recht a is ow systeen van geldings en competentieregels en van rege is die de formele ver enigbartheld wan rechtsregels reguleren, wararoor de rechtsgeldigheld van rechtsegels bepald is door andere kemmerken dan hun inhoud, namelijk wam kermerken en van zulver loglsche, temporele, nulmtell like of regellhlerarchische aard. Dergell jke regeis worden belangr ljke naarmate een rechtsysteem meer geoosit iveer o raakt, dat wil zeggen naamate de gelding van regels meer af hankelljk wordt gemaditt van wen wederom ap formele wIJze te bepalen corsorong van rechtsegels. Al deze regels, behalve dle wan de loglca, hebben echter potentleel ook een materlelle fumder ing van ldeolog lsche aard. In princlpe is het mogeIJjk zlch wan alle formele aspecten nlets aan te trekken en een rechtstreeks bercoo te doen op dle mater le funderlng. Bezwaren van formele aard kunnen dan opzl」 worden geschoven, maar we verlaten daarme het terrein van de Jurldische beschouwing In strlkte zin en betreden dat wan de morele en polltieke fllosolle. Let wel: ik zeg nlet dat dit soort overwegingen nlet thuls horen in een Jurldisch betoog, maar allew dat het betoog slechts Jurldisch karakter heeft worzover het formele kader nlet opzlJ gezet wordt. Dok binnen dat kader billft heel wat ruimte voor overweglngen van polltilek-fllosof ische en ethische aard en Julst dile rumte bll Jkt veelal onvoldoende gexwloreerd te worden (3).

Blijven we nu binnen dit formele kader, dan is het mogelljk de structurele elgenschappen van rechtsordes als een geheel van normen rechistheoretisch te bestuderen, waardoor de elgenschappen ervan worden georeciseerd en It het bljzonder de grenzen van dergelljka systemen worden bepaald. Dit soort studles hebben th pr Inclpe welIswaar een extern karakter, maar ze hebben In dat geval nlettemin directe interne consequentles, als men zlch an net formele kader Intern gebonden acht. In mIIn betoog in "Grondwet en krulswlluentwapens: (4) bljvoorbeeld, heb Ik een rechtstheoretisch gefundeerde stelling met intern-Jurldische relevantile gebrulkt.

Tot zover dan mijn betoog over de afgrenzing wan metajur ld laca 
als verzamelling wan diswiplines warvan de inhoud afhankellik lis van het soor fllosol lsche of menswetenschapolijke disclpilme warin recht tot object wan onderzoek wordt gemalkt. De verscheldenheld wan metajurldische disclolines is thans al zo enom, dat geen normad mens ze meer allemaal wolger, lat staun beheersen kan. Het is l eem hele kurst om de ontwkkelngen oo het terrein van slechts ven van de vele subdiscipl Ines blinen de metajur idlca blf te houden. Wle zlch nlet soeclallseert Is senwoudig gedoemd een bloculge amater en eclecticus te blijven.

Zoin speclalisate kan in princlpe drle wormen aannemen. Men kan zlich speclallseren in en bepalde disciplline bljwoorbeeld de rechtstheorle de rechtepsychologle, de rechtseconomle of, en dat is de tweede worm, men kan zlch speclallseren op een bepaalde thematlek, bllwoorbetd criminalitelt, wetgewing, rechtsvinding, bewllswoering, Jurldische bercopsgroecen, enz. warbl] men invalshoeken wan vershill lende metajuridische disciplines comblneert.

De derde worm wan poclasate is dle warvoor ik de term imetajurldica in enge zin zou wllen reserverem. Daarln staat de analyse van de ontwikkeling wan het jurldisch denken centraal. Het Jurldlsch denken kent verschlllende nlveaus, de ontwlkkeling van regiels en rechtsinstituten, de lleer van de toepassing en ontwikkeIIng van regels, ook well rechtsvinding genoemd, de interne bestudeIring van recht of de rechtsclogmatlek, en tenslotte de soclaal-wetenschappellyke, de rechtstheoretische (loglsch en structuur-theoretische) of de rechtsf I losoflsche (normatlef-ontologische) bestuder lng van recht (5). Behalwe de ontwllkikeling $\infty$ al deze niveausis met name ook de wilsselwerking tussen de verschll liende niweaus van belang. Voor metajurllalca in deze derde ziln is metajurialca in de twe eerdere beteken hssen zowel object ais hulpwetenschap; object, omdat ze deel gan ultmaken van het denken over recht, en hulpwetenschep, omdat ze kunnem helpen verklaren waarom het Jurldisch denken zich onder bepaalde omstandigheden oo een bepaa ide wilze ontwlkkelt. Metaluir/allica in ange $z$ in is met andere woorden kennism soclologle en kennistheorle van het recht. zIJ verhoudt zloh tot metajur lallica in rulme zin oo dezelf de wijze waarop de moderne wetenschapstheor le zlch verhoult tot de wetenschap. Ze gebrulkt we- 
tenschappell Jke theor ledin on wetenschapsontw likkeling te verklaren en becordeelt wetenschapsontw Ikkellng tegelljkertlla onder het gew $z$ lchtspunt van haar vermogen on problemen of te lassen en om constructlef of de oude problemen woortbouwend, nlewwe problemen te genereren. De moderne wetenschaostheorle staat daarbl」 In een cirm culalre verhouding tot de wetenschap en tot zllchzelf. Sinds de wending naar het crlticlsme onder Invloed van Karl Pooper Is de wetenschapstheor le zlchzelf hoe langer hoe meer an clezelf de orltorla gaan onderwerpen als dle welke ze aan har oblect meent te kunnen constateren. Moderne wetenschabstheorle zlet zlchzelf derhalve anders dan de tradtionele fllosofle, nlet als transcendent of transcendentaal ten opzlchte van de vakwetenschappen, maar a.s. een immanente reflectle erop, dle en bljarage aan levert en zijn object kan beirwloeden en veranderen.

Metajurldica In enge $z$ in Is derhalve lets anders dan rechtstheorle, want het maakt ook de rechtstheorle tot $z$ lin object en zlet ook rechtstheor le als ultarukking of instrument voor de formulering van colossingsstrategleen wan Jurldische problemen, zonder over 1gens enlge pretentle van theoretische superlorltelt ten opzlchte van de recintstheorle.

Een wan de belangrljkste Inzlchten waartoe de modernere wetenschapstheorle heeft geleld, Is dat conditles van rationalltelt van wetenschap nlet onafhankell.jk van soclale, allgemeen culturele en Intellectule conditles kunnen worden bezlen, evenmIn a is onafhankellflk van het soort problemen dat ter opllossing staat. Gegeven probllemen kunnen bl॥gegeven condltles vaak langs verschll lende wogen worden aangepakt of zelfs worden oogelost (6). Wat vooral van belang is voor woorultgang in het denken is dat er voldoende varlam tle aanwezig is alsmede selectledruk. Deze visle op rationalitalt van wetenschappell Jk en bulten-wetenschappe II Jk probleemop lossend deniken, impllceert cok en andere visle op de waarde van bultentheoretische factoren. De Inwloed van persoonlljke en soclale factoren in de ontw lkkelling wan het denken is nlet a prlorl negatlef te waarderen, mits deze de varlatle in het denken stimuleren en de selectledruk niet ondermljnen. Op grond van deze ultgangspunten wll ik nu gaan kljken near de ontwlkkeling in de privaatrechtsleser in 
Nederland in deze evw. Mu stelling zal zl In dat flink weel varlatle was en ls, maar dat als gevolg van nader te releveren factoren slechtes zen zer lirge selectledruk was of, alls men wll, Julat een te sturke druk, maar dan een cruk dle werkte in de rlich whing wan hewalling of parafrasering wan reeds berelkte resultaten. Daardoor is de vooruttgang in het rechtswetenschacpell jk denken gehinderd en, ds gevolg daarvan; ook de verhogling wan het theoretisch gehalte wan wetgewing en rechtspraak, waarbill ulteraard interactle plaatswond tussen dle twee niveausi van Jur idisch denken.

3. De dlalectlek van heer- en knechtschap in het recht.

Laat lk maar meteen mIIn kaarten open op tafel goolen en mijn globale wisle geven op de ontwlkkeling van de rechtsleer in deze eeuw, In het bljzonder oo het terrelin wan het pr lwatrecht. Met "privaatrechtsleer" doel ik hler op de meer algemene lideevn over object, methade en de fundamentele begrippen wan het privaatrecht. Deze 2 Ijn mljns inzlens in hoof dzaak bepald geweest door het probleem wan de verhouding tussen wetgever en rechter en wel In die zin, dat de privaatrechtsleer zich wooral heeft ontwllkkeld is leglt lmatletheor le van een global gezlen in deze euw steeds verder toegenomen vrllfheld van de recinter ten cpzichite van de wet..

Tegen dle ontw lkkellng heb lk twe bezwaren. Het eerste bezwaar Is, dat deze theorleen weinig of nlets hebben bligedragen aan een Inhoudel|jke methodologle. Ze bevatten weinig aanwiljzingen over de wijze waarco oo en controleerbare manler met dle rechterlijke Wrillheld moet worcen omgegaan, laat staan dat er ook nog lets ult zou kunnen worden afgeleld over de wljze waarop wetten optllmaal in elkaar gezet kunnen worden. MIJn tweede bezwaar is, dat de verdeling van rechtswormende macht over rechter en wetgever in princlpe geen kwestle van Jurldische methodenleer is, maar een staatstheoretllsche kwestle, hoewell het antwoord op deze laatste well weer bepalend kan zlijn woor het soort methodlsche kwestles, waarmee de rechter geconfronterd kan worden.

In een democratische rechtsstaat, moet het als een paal boven water blijven staam dat de rechtsvorming in princlpe (dat wil zeg- 
gen binnen gegeven const lut lonele grenzen) thuls hoort bli de poIlt leke organen en nlet bly de rechter. Met dat laviste will Ilk nilet zeggen dat de rechter a is het ware mechanlsch de wet zou moeten toepassen en ook nlet - oulten het strafrecht - recht zou mogen vormen In dle gevallen, dle de wetgever nlet voorzlen heef. Maur als de rechter dat doet, moet hil Ideallter anslulten bll het in de wet gepositiveerde recht. Bl] dat ansiulten bl] het geocoltiveerde recht $z$ IIn de rechter ongetwlJfeld vele vrljheden gegeven. In belangrlljke mate is dat echter het gevolg van het felt dat de wetgeving in methodolog isch opzicht onderontwiklkeld gebled is. Juristen zIIn tradltioneel vooral In rechtspraak of slechts in de Interpretatle van wetten geinteresserd geweest. Mlln stelling is nu, dat het gros van de Jur Isten blJ dle onderontw/kkeldheld wan de wetgevingstheorle nlet alleen door cle tradtlle bepald belang heeft. Alom hoort men wellswaar het ach en wee over de kwalltelt van wetgeving, maar dat men daar nou werkelljk zo vreselljk mee zlt, waag lik te betwilfelen. Slechte wetgeving Impllowert Immers meestal grotere vilJheld blj de ultwoer ling en de toepassing van de wet en heel vaak ziJn het Juplsten, $\infty$ wle dle taak rust. De mate waar In de kwalltelt van wetten van belang is, is afhankelijk van de functlle dle en wet moet verwullen, en hetzelfde kan gezegd worden van de aard wan de kwalltelten van de wet, waar het op aankont.

Jur isten worstelen met dr levoudig structureel dilemma. Dle drle dllemma's z IJn nauw met elkaar verbonden. Het eerste dilemma is dat tussen rechtsmegel en blliljkheld in het concrete geval. Een regel dle in het algemene geval verantwoord Is, kan in het concrete geval wel eens tot wreemde resultaten lelden. Om lin dat concrete geval een ultzonder Ing toe thas, zou, als de schlln van wlllekeur vermeden wil worden, wederom ben beroep op ren regel gedaun moeten worden en wel een regel van hoger niveau. Datarme nemt echter de complexiteit van het regelsystem to en wordt het bowern dilen moelly om in een nleuw gevel, wasin ook deze ultzanderringsregel nlet hellot dan wel julst tot een angewenste besilsing dwlingt, toch weer en ultzondering te maken. Dlt dllemma makkt het begrljpelljk, dat we in de rechtspraak zo valk van dle onbepaalde formules als "In de gegeven onstandigheden' of 'In het onderhavlge 
geval tegenkomen. Zuike formulles suggereren een of andere nletsubjectleve matstaf met behulo warwar de gegeven omstandigheden op voor de besl issing relevante wlyze van andere omstand Igreden zouden kunnen worden onderschelden, zonder dat meestal de regel waraan de matataf wordt ont lend, gexplliclteerd wordt. Het dllemma leldt tot regelangst angst woor overoomplexitelt en angst voor ais gevolg van overcomplexitelt noch ratlonalliseerbaar, noch verheellbar subjectivlsme. Cegeven deze angst heeft in het bljzonder de rechter, dle besilissingen geeft $\| n$ mlet-gestandaardiseerde Indlviduele gevallen, behoefte aan rulme, wrlJ vage regels waar In het onderscheld tussen regeltoepassing en subject/wisme min of meer mistig kan blijven. Alleen als externe druk oo de rechter wordt ultgeoefend om z'n besllssing mader te legltimeren, zal hl behoefte hebben aan ultworlgere en preclezere regulering. Dat zal het geval zIJn als z lch georgan iseerde be langengroepen gaan roeren. Het eerste dillemma wil ik het regel-ultzonder Ingsdliemma noemen.

Het tweede dllemma is als het ware het negatlef van het eerste. Ik noem het het dllemma wan de Jurldische anomle. Recht dient Immers nlet alleen de beslechting van indlwluele conflicten, maar het heeft ook een gedragsturende en or lenterende functle. voor dat laatste is veelal Julst en redelljke mate van volledigheld en precisle van regels gewenst. Met name waar het gaat om complexe vormen van soclale interactle, is de functile van recht nlet primair de regulering van confllctem, als wel het mogelljk maken van een vlotte gang van zaken in het sociale verkeer, het aanbleden van vormen van soclale Interactle door distributle van rechten en verantwoordell Jkkeden, het aangeven van procedures en het vastleggen van afsoraken en besllssingen. Hoe compllexer net socla le verkeer, des te gevarleerder en gestructureerder het recht moet worclen. Howel conflicten in dit verband secundeir zljn, is de wijze, warco de rechtspraak confllcten oolost, toch wam belang voor de stabllitelt en de vern leuwing van net regelsysteem. Zouden rechtiers zlch wat al to veel vrluheden permitteren of vermieuwingen teweeg brengen, dle nlet goed aanslulten bly het bestaande, dan kan het bllnde vertrouwen in de normale werking van het maatschappell.jk verkeer worden aangetast. Met "normale' werking bedoel IK over Igens. 
nlet: "overeenkonstig de regels". Rechtsregels worden in de prak-

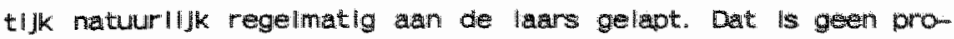
bleem, zolang men zlich maar min of mer conformeert aan de informele regeis van het soclale verkeer, ook dan echter blliken recthtsregels weelal een soort 'reserve-functle te wervillen; enerzljas woor andere doeleinden dan de door de wetgever beoogde, anderzljus woor het geval 'normale' werwachingen nlet ultkomen, bllwoorbeld In geval van falllissementen of bij wilze van stok achter de deur. te gebrulken tegen dlegenen dle zloh in wet wensen te voegen nawa de Informele normen (7). Valt deze reservefunctle van het rocht weg. dan kan het ook gedaan ziln met het vertrouwen In de Informele onde. Er treedt een toestand wan Jur ldische anomle Im. Behalve een gevolg wan een tekort aan functlonele regels, kan Jur lalsche anomle cok het gevolg zilln wan overoomplexiltelt van regiels, door gebrek aan selectle of te tijdrovende selectle van regels als gevolg van te grote of inconslstente differentlatle en overlapoing. Het dilemma van de Jurldische anomle is derhalve beoald door het contlnue gevaar van onder - en ovcomplexltelt.

Het derde dllemma slult aan blj de erste twee, mar bewegt. zlch in een ander dimensle namelljk die van de organlsatle van de rechtsvorming en die rechtstoepassing. Toenemende complexltelt van de samenleving leldt onvermijdelljk tat mer spociallsatle in de sociale controle. De speclallst glerakt dan ochter in het dilemma van professionalltelt en legltimltelt. Aan de ene kant is het de soeclallst dle meent beter dan het grote publlek te kunnen bepalen wat goede regels $z$ IIn en hoe regels Julst moten worden toegepast. Aan de andere kant moet hll de afnemers van $z \| l$ jn besilssingen ervan Kunnen overtulgen dat ze betere of althans geen slechtere waren geleverd krljgen met in plaats van zonder peclallsten. Dit probleem wordt dringlender, naarmate de sociale afstand tussen speclaIIst en fnemers groter wordt. De legit/matle van de Jurlalsche speclallst is - op het continent althans - sindts de vorming van de nationale stakt nlet meer de gehelligde traditle van het recht zelf maar" wordt ontloend aan de voorschr Iften wan het stastsgezag ten aanzien van de geldende rechtsbronnen, waarblj de wet ean steeds prom inentere plats heft getiregen. De positle van de Jur lst 
wort daame echter wel zeer onaantrekkellyk. HIJ wordt gereduoerd tot en soort instrument van de staatsmacht. Onder die omstandlgheden ligt het voor de hand te verwachten, dat Juristen zullein pogen en nleuwe basis te vinden woor grotere autonomle, c.a. hogere soclale status. Dle dwang zal $n$ het bljzonder groot worden, als de polltleke consensus gaat afbroklkelen, zoals in het latste kwart van de vorlge eeuw, toen de "soclla le kwestlea hoe langer hoe mer ging spellen.

In dile per lode waren wler mogell Jkheden voor en theoret lsche bas is van grotere autonomle van Jur Isten ten opzlchte van de staat. De erste was dle in de vorm van quasl-soclologlezn, dat wll zeggen de functlonallsering van recht in termen wan nlet door de overhell, maar door de maatschappell lke ontw'lkkeling zelf ged lcteerde facto ren (bljwoorbeld de soclaal-darwinlstisch geinsolreerde "Interessenjur lsorudenz" van Jherling of, In ons land, de opvattingen van H.J. Hamaker). De tweede mogell Jkheld waren psychologlsche theorllen over de oorsprong en werk Ing van rechtsgevoelens (billwoorbeeld de "Frele Rechtschule', in ons land bivvoorbeeld I.H. HIJmans en de Gronlingse school van G. Heymans (waartoe Polak, Kranenburg en enigszins ook Krabbe gerekend kumnen worden). De derde mogelljkheld waren existentlallistlsche, rellgleus of natuurrechtell]ke getnsplreerde waardefllosoflen (bljwoorbeeld Scholten, Dooyeweerd). De vierde moge IIJkheld was analyt|sche verwetenschappellyking, dat wil zeggen de ontwlkkelling van structuurtheor leen en methodolog leen (consistentle, coherentle en precisie), waardoor de wlllekeur van zowel wetgever is rechter zoul kunnen worden beperkt (bljworbeeld Meljers, dle deze benderlng heft verbonden heft met en over lgens welnig ultgewerkt ut:llitar $\mid$ sme).

De mogelljkheld wan analyt ische verwetenschappelijking is echter weinlg antrokkelljk, doordat ze de Jur ist niet pr Inclples ontdoet wan zllun rol wan krecht van de owerheld. Aatlonallserllng is Immers uen tweesnl Jdend zwaard. Wellswaar stelt het zekere grenzen aan de stalamacht, maar het ontneemt ook autonomle aan de Jur ist, in het bl)zonder aan de rechter die geconfronteerd wordt met concrete personen en partIjen, waarbl] het regell-ultzonder Ingsd llemma acuut kan worden (8). 
Hifarkellik van de gekozen otle en de Introud van de theorle zal het accent van de verdellng van de rechtsworming anders liggen; hetzl] bll de wetgever, hetzl] bll de rechter. Voor dis verde mogem llikheld is thet in en enlgszins dymamlsche samenlewing willwel onverml Jdellilk, dat de rechtsvorm Ing in hoofdzak zal to bomen man de wetgever en nlet aan rechters, in de functlone zin van lledien, die Individuele conflicten besiechten op grond var offlolshe regels. De Jurist kan in deze benader ing alleen maar grenzen trekken dan wel reods in het posltleve recht gegeven lljnen verder doortrekken. Ulteraard kan de Jur lst wel pogen het wetgevingspocoss te beinvloeden door pollticl de voor-en nadelen van de diverse regelingsaptles voor te houden. ZIJn positlie is echter princlpleel die van een knecht, een technlcus dle geen zelfstandige, InhoudeIIJke Invioed kan ultoefenen op de ontwikkelling van thet recht. bit laatste is natulurlllik een voor vele Jurlsten weinig aantrekkelljke optle, een cotle dle nlet correspondeert met het traditlonele beroepsbeeli van de jurlst (9). Deze aptle is des te onaantrekkelliker, a is de Jurist meent dat de staat nlet te vertrouwen is, dat will zeggen nlet de belangen dient van de soclale klasse, warar hil zlch mee ldentl lceert. Heel veel Juristen hebben begrlJpellJkerwils de Intrede van soclalistische partljen in de polltieke arena als een bedrelging van de polltieke en soclale orde gezlen.

4 Het Nleuw Burgerlljk Wetboek ais "unzeltgembses" verschillnsel.

Bezlen we nu op globale wijze de privaatrechtsontwikkelling in deze euw, dan kan worden gesteld, dat terw 1 ll de wetgevende culvitult wan de overhela sterk is toegenomen, de rechtsleer $z^{\prime} n$ autonomle vooral gezocht heeft In het ultbaten en tegelijkertija onbestemd laten wan vage normen, door het werken met een mogal difuus bllIIJkhelosbegrip en en toenemende inate van casulist/sche rechtsvinding, dat wll zeggen het nemen van beslissingen van geval tot geval met een betrekkell Jk geringe mate var ratlonallser Ing van de casultstlek In termen van algemene lexstukken, Overlgens moet hler natuum ll lk worden opgemerkt, dat prima ir de wetgever verantwoor do- 
IIK wle rulnte heeft gegeven voor betrekkellik vilje rechtsvoming. Dit is desis het gevolg van politieke onmacht (bljwoorbeeld het stak Ingsech), deels van orverschilligheld ten opzlchte van in politlek opzlcht nlet interessante onderwenpen, deels vain onvermogen de casuistlek van te voren te kunnen overzlen. ook zijn polltlol glenelgd middels vage normen en kaderwetgeving tegemoet te komen aum polltilice verlangens zonder dat men veel ldee heeft over de verder concretisering vain zo'n wet of zelfs met de helmelljke hoop, dat de wet een dode letter blllft, malar wel als polltlek compromis als placebo voor de werseri wan hum achterban kan dienen (symboolwetgeving).

Giezlen vanult de belaingen wan Juristen is dit helemaal geen gek arrangement. Rechters zullen op deze wijze het nodlige In de melk te brokkelen hebben, advocaten behceven nilet zo zeer rechisgeleerd alswell retorlsch begaafd te zlin, terwill beleldsambtenaren een grote mate van rulmte krijgen tot rechtsvorming. Echte problemen ontstaan elgenll jk pas a is het erom gaat om ingrljpende en omvangrijke wetswljzlgingen lin betrekkelljk hoog tempo door te voeren. Het tempo erwan kan aanzlen ll lk gedrukt worden door de moellijkheld om net geldende recht te overzlen, de problemen in net recht te localiseren en op te lossen en de potentlelle problemen van nleuwe regels te Identificeren, en dit alles nog geheel afgezllen van een waak groot gebrek aan kenn Is van het maatscheppell Ik terrein waarco de wetgeving moet gaan functloneren. Deze probllemen worden versterkt door het felt, dat vele kwestles van wetgeving geen polltleke actuallteltswaarde hebben, en dat het aantal Jur isten in de Tweed Kamer ger ling is. Natuurlijk is het zo dat het voorbereldende werk bij de wetgeving gedaan wordt door ambtenaren, die zich op het betreffende trein meestal redelljk Inglewerkt zullen hebben. Dit. soort woorbereldend werk wordt echter vaak marar door man of wrouw of slechts heen klein groes ambtenaren gedaan, en deze zl.jin bowendllen sterk gebonden aan de polltileke alrectlewen die zlj cntvangen. Het perspectlof van warult $z \|$ J wetgeving $\mathrm{min}$ of meer natuurlljkerw I bs benaderen, is dat van de overheld en nlet wan de ander groepen van het matschapoell lik terreln waarop de wetgew ing moet gaan functloneren. 
Bezlen we tegen de geachetste achtergrond de ontwikkeling van de privaatrechtsleer in deze euw , dah zlen we het paradoxe fenomem wan en glabaal steeds toegenomen rechterlljke willheld on en poging tot vernleuwing van dat recht in de vorm wan het Nleww Burgerll lk Wetboek, een ondernem Ing dle nu al veertlg Jabar gaande is. Hoe is dit laatste nu verkllarbaar in the lloht vain bowengtande analyse, waar in en dergelljke ontwlkeling nlet past. Dle viaag is des te klemmender, gezlen het fielt dat met de hroodlflatie van het pr lwastrecht - In het bljzonder zoals die In 1947 werd opgevat - ls zodanlg toch nog geen grote matschapelljke belangen en vernleuwingen gemoeld waren, dle zouden kummen rekenen oo veel Interesse van de kant wan pollticl.

Deze vraag orlingt te meer nu we weten wat er na de opdrachtverlening tot hercodiflcatle aan Mel Jers allemaal gebeurd Is. Het NBW heeft een bultengewoon moelzame geschledenls doorgomakt on is door de nodige tegenslagen getroffen gewt. De glor le watrmee men er In 1947 an begonnen is, II.kt wolledig vergaan; geen beter bew Is dearwoor dan dat een half Jaar geledien geen enkel Jurldisch tijcschrift het de moelte waard wond te memoreren dat 40 Jaar geleden aan Meljers de codracht verleend werd. Kennelijk is dat al een al te pljnlljke herlnnerlng. Het kan ook werwonderen. dat de onderneming al dle veertlg Jaren over leefd neeft. Gelljk bekend ziln er de nodlge 'sabotage'-pogilngen ondernomen.

De geschleden is van thet NBW is te allgemeen bekend on har hler te herhalen. Wat een via glor losa had moeten ziln, werd cen Vla dolorosa. Geen wonder, dat thans ook vele voorstanders wan Invoer.Ing wan het NBW en ook vele voormallge medewerkers an het NEW; menen dat men er achteraf gezlen wellicht maar helemal beter niet an begonnen was. Dit nlet zozeer, omdat het indproduct kwalltatlef gezlen nlet zou mogen zlJn, maar omdat het zoin ongehoord langdurlge en plunllike bevalling is geweest, die wellswaar de nodlge Jurldische woorultgang met $z$ leh meebrengt, maar voor de rechtspraktijk in het algemeen nlet van erg Ingrijpend belang zal zijn. Bovendlen erkennen ook de voorstundersi van de unvoer Ing, dat deze de nodlge kosten en abassingspoblemen met z loh mee zal brengen (10). Sommilgen, zoalsi Snljders bljvoorbeld, zlen de lange duur wan 
het project echter julst a is een voordel, omdat herdoor ween weel groter deel van de matschappellJke ontwlkkeling door het NBWH IS "megenomen", amoel gelegenhelid is geweest om over het ontwerp

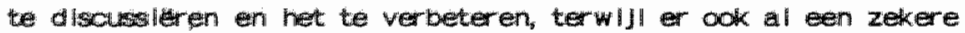
gewenning an hat Naw heeft platugevonden via de antliperende Interoretate. Daar zit ongetwiffeld wat in, maar aan deze overweglingen zilln milns inzlens op zlchzelf genomen ook brulkbaar ais argumenten tegen hercodlflcatle en voor het door Van Dunne voorgestelde, an de VS ontleende systeem van 'Restatement of the Law' (11). In dit verband 211 ook gewezen oo het nog onopgeloste pro bleem van wat dilent te gebeuren, als het NBw eenmaal is Ingevoerd. Het mljns inzlens verstandlge ldee van MelJers om het BW eens in de tlen Jaar bl] te werken, ls alleen ultvoerbaar Indien de wetgevingsmachine le op wille zou functioneren, en onderwemp waar lk later nog terug zal komen.

De stelling: "We hadden mar beter nlet aan kunnen beginmen" Isis 20 n typlsche wijsheld achter af. In 1947 was meni in het algemeen zerer lingenomen met de plannen tot hercodiflcatle. Zelfs Pltilo, later fel crlticus van het NBBW, stelt in 1964, als hil zlin eerste kritlek op het ontwerp-erfrecht formulleert, dat hilj tegen hercodiflcatie oo zichzelf nlets in te brengen heft. ZiJn bezwaar is dat Meljers zich nlet wan zlin opdracht gehouden zou hebben, namell.jk een zulver technische herzlening (12). Men kan erover twisten of Meljers $z$ llch wel of nlet aan zljn opdracht gehouden heeft, maar kan evenzeer aall getwljfeld worden of de geschlede$\mathrm{n} / \mathrm{s}$ van het NBW erg anders zou ziljn verlopen als Meljers zich wat meer had Ingehouden wat betreft vernleuwingen. Andere critlicl wan het NBW, zoa Is SchoordiJk en Van Dunne, hebben Immers betoogd, dat het Nibw Juist daarom bedenkelljk is, omdat het in sommige opzlchten achter" zow lopen blJ de feltelljke ontwlkkellingen in mevatschapolJ en recht die zich na de Tweede werelcoor log hebben voom gedaan. Met andere woorden: had MelJers zllch gehoudlem aan de opdracht van een zulver technische herziening, dan was wellicht al gau de kr ltlek gekomen dat de hercodificatle zou moeten worden aangegrepen om rechtsvernilewwend oo te treden. Uiteindelljk was dat cok de tijdgest: van de nacor logse per lode: de samen lleving moest grondlig wor- 


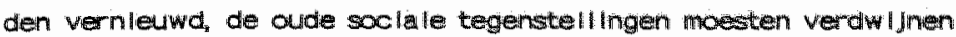
en de stat zou daarbly actlef moeten otrecen. pltilo's lkt lek $\infty$ het erfrech is bovendlen nlet van Juridisch-techilsche ard, Integendeel. hil is daarover in het algemeen wol lof, maar het zinn materlele vernleuwingen die hem tegenstaan, ook al erkent MlJ dat dle in belangrlyke mate aansiulten bly feltelljke ontwlkkellngen in

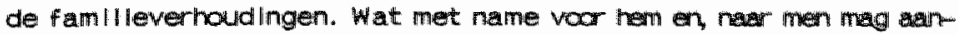
nemen, in nog sterkere mate voor het notar laat steen des anstioots was, was Meljers' voorstel een boedelrechter te Introduceren wardoor vanzelfsprekend de staat meer grees zou krilgen op de afhandelling van erfenlssen. Wat Pltio ook sterk afkeurde, was de zlJns Inzlens overdreven versterkIng van de positle wan de over levende echtgeno(o)t(e) ten koste van de andere legitimar Issen, een lkwestle waarover men het na veertig Jaar nog steeds nlet eens $1 \mathrm{~s}$, en wel ondat er binnen het notarlaat zelf zeer verschlllend over gedacht wordt, woornamelljk afhankelljk van net soort cllenten dat wor ot bedlend.

Hoe dan ook, P\|tio is pas na 1954 echt gaan ultpakken tegen het: NBW en wel op manler dle rem In lscentles oproept an de argumenten tegen codiflcatle van het Dults privaatrecht, zoals Karl Frledrich von SavIgny, de stichter van de Historleche rechtsschool in 1814 naar voren bracht (13). Aan de ene kant het bezwaer dat codlflcatle zou lelden tot een breuk met het histor isch gegroelde, aan de andere kant het bezwaar, dat de wetenschap op allerlel terreinen nog onderontwikkeld of volop In beweging is ("4) , Zo'n bezwar gaat In een moderne samenleving natuur IIJk altuJj $\infty$. Aan de ontwikkeIIng van de rechtswetenschap komt noolt een elnd en zelfs oen wat langere rustper lode in de ontwikkellng is in mon modern sumenleving nauwelliks warschijnlljk. Pitllo koketterde graag met rao tionalre denkbelden, zodat men blJ hem dit soort argumenten nog wel verwachten kon, ook all ge loof ik nlet, dat hil zlch oot bevust geweest is van het felt, dat zIJn voornaamste bezwaren all bly vorn Savlginy ziln aan te treffen (en de echo daarvan komt men In de pr vaatrechtsgeschledenls wan de negentlende en twintlgste evw voortdurend tegen). Deze bezwaren kan men bljwoorbeld sok belu hister en blj de enlge nog rester ende opponent tegen de Inwoer Ing van het NEW 
onder de hooggelesde or Ivatisten, Van Dunre (15), Wan Dunine zlet zlchzelf" wellicht terecht, als een progressleve geest. Mogelljk Indlceren deze door Pltio en Van Dunne gedeelde bezwaren daarom lets wan het collectlef onbewuste wan de privatist.

\section{De echo van von Savigny.}

De stulling Achter gezlen hadden we noolt aan moeten beginruen zal ongetwljfeld wreemd in de oren klinken van de gerniddelde nlet-jurlst, woor wle ingrljpende veranderingen van wetgeving Immers thel normall verschl Insel ziljn geworden. Hoe is het toch mogellik; zo zal de nlet-Jur ist vragen, dat Jur isten zo opgewonden kunnen raken over een maatschappelljk betrekkelljk belangeloos gegeven a ls het algemeen deel van het vermogensrecht? De leek zal $z$ lch kunnen voorstellen, dat men zlch kan opw Inden over vernleuwingen in het personen-, famillo- en frecht. Nlettemin zall het voor hem nlet goed te begrljpen zlJn, dat men nog na veertllg Jaar clsm cussle voert over kwestles vain erfrecht, dle lin wezen polltleke knopen z IJn die door het parlement zouden moeten wonden coorgehakt. Waarom, zo zal de leek vagen, is herzlening van privaatrecth zo lets fundamenteel anders dan her $z$ lening van veel andere wetgeving? Een overtuigend antwoord zou lk nlet kunnen geven. Maar Ja, lk kan op het terreln wan het privaatrecht ook nlet zo gek veel meer pretentles nebben dan de gemlddelde leek. Wat Ik wel kan zeggen, is dat het de knollentuln van de Jurlst wes en Is. Ik laat nu het collectlef onbewuste van de rechtgeaarde privatist spreken: afgezien van het strafrecht is privatrecht heel lets anders dam alle andere soorten recht, waroo de molht geaarde privatist neerkilkt als op parvenu's. Het privatuecht is het rectht war de wetgever

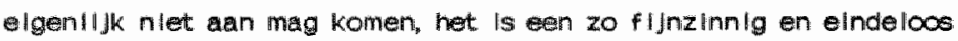
In de loop der euwen ultgespannen netwerk, dat hercodlflcatle tot een rampzallge breuk met de tradltle zoul lelden. Kleine behoedzame vernleuwing is nog wel aanvaardbaar, maar absoluut geen "grosse Wurfe" warvan de consequentlles nllet te ovezien zlln. Ean hieraan parallel lopende kritlek is dat prlvaatrecht wezenlljke casuTstlek is en dat rechtsvinding in het privaatrecht altijd rechtsvinding in 
concreto is. Wetgeving in het privatuecht is in deze visile woorel de neersiag wan het in de casuistletc ontwlkkelde recht, het geveft er nlet rechtstrecks vorm aan, maar legt het vast. Wat wel vorm geeft aan het prlvatrecht zlin centrale ldeedn als de autonomlege dachts, het vertrouwenseginsel, de zorgwuldigheld in het mateschappelijk verkeer, en de redelljkheld en blllikheld. Deze zijn echter als zodanlg te vaag en moeten casuistlsch worden ultgewerkt. Oo zlchzelf kan het prlwatrecht net zonder wettelijke regels stelIen, zodra de casuistlek rijk genoeg Is. Daarblj heeft afwezlgheld van wettelljke regels ook en voorden, in dle zin dat het recht zich soepeler kan aampassen aan nieuwe maatschappell Jke ontw lkkelingen.

De nllet-Jurist zal $z$ lch natudr ll jk verbaasd afvigen waarom zo"n zelfde verhaal nlet zou opgian voor vele andere rechtsgebleden. De privatist zal hler wellicht op antwoorden, dat het daar altljd gaat on polltleke verhoudingen, die nlet varult: 'natuurll jike' verhoudingen tussen mensen onderling als gelljken in het maatschappell.jk verkeer, the begr ljpen ziJn. Werpt men dan tegen, dat vele prIvatisten nu toch Julst prat gaan op het soclale karakter van het moderne pr I vaatrecht, waar in woortdurend de zwakkere part. IJ beschermd wordt tegen de sterkere, dam zal de privat ist betogen, dat er in het prllvaatrecht sprake is wan een natuurllifke maatstaf waraan de mate van de door het recht te compenseren ongelljkheld kan worden afgelezen. Dle maatstaf ontbreekt aan het publlekrecht, doordat we daar te maken hebben met verhoudingen waar In sprake is van princilplele ongelljkheld van partljen en van bijna altljd eenzljallge rechtsverwerhoudingen: de overheld vordert lets van de burger of omgekeerd, maar van wederkerligheld is zelden sprake.

Wat opvalt In het betoog wan de prlvatist, is de ethisch-personallstische Inslag ervan. Pollitieke motieven, maatschapolljke ratlonallteit en efflchentle lljken wan ondergeschikt belang of worden geacht in het ethlsch-personalistisch model als wla even onzllchtbare hand gerealiseerd te worden. Er is sprake van natuurHIIke gellykheld of althans van een natuur Iljke maatstaf ter vaststelling van de conditles van gelljkheld. Tegengeworpen zal welllont worden, dat mlin weergave van het pr lvat/stische denken on- 
wolledig is, ondat de madtstaven van redelljkheld, bllljkheld, veruouwen e.d. ontleend worden aan de feltell jke genulalgde covatingen daaromtrent en niet aan es of anclere fllosol lsche maatstaf. Deze tegenwerping lis deels terecht; matr deels cok weinig overtulgend. Verondersteld wor ot namell $k_{k}$, dat en hoge mate van maatchapplljke consensus zou zlln over wat normaal en fatscenlilk Is. Dat lljkt echter gezlen de plurlformltelt van de samenleving en het nog steds toenemend Ind viduallsme, hoe langer hoe onwaarschl.Jnllyker. Veel onderzoek naar de publleke oplnle wordt er in cie recintspraak in leder geval nlet gedaan. Bovendlen kan de vraag gesteld worden wannee warom de publleke opinle gevolgd moet worden. Het beeld van het privaatrecht dat in de ultleg naar aanlelding wan de vraag "Waarom is het zollets bljzonders? gegeven is, komt mil hopeloos romant lsch en ouderwets woor. Het gaat ult van lodeetn over natuur II lke ontw Ikkelling, gelljklheld en socla le harmonle, terwill de scclale realltelt Julst grote ongelljkheld, belangentegenstell Ingen en snel le werander Ingen wan de technlsche, esonomische en soclale verhoudingen te zlen geeft. Bll dit alles komt dan nog het felt, dat colk de overheld zich regeimatlig van privaatrecht bedlent en dat in die verhouding beginselen een rol kunnen spelen dle met het prlvaatrechtiell ljke denken op principleel gespannen woet staan. In felte zlJn dat soort beglnselen echter minder typlsch voor de overheld dan wel gedacht worct. Zodra er sorake is wan grote verschlllen in kenm/s, macht en bezlt zullen wil In het varwater van de pollttlek terecht komen en kunnen wIJ met besplegoIIngen over simpele Intermenselluke verhoudingen nlet veell verder komen. En zelfs is or geen sprake is van grote verschillen in kennis, macht en bezlt. kunnen matschappell.jke overwegingen in plats van interpersconlljke blllljkheld, de doorslag geven. Laten we alls voorbeeld net probleem van de keuze tussen rislco- en schuldaansprakel II kheid nemen. Neder landse Jur lsten praten daarover In het algemeen in (quasi-)ethlsche termen. Dle ethische benadering, dle mogelluk 'recht' doet aan het indlwiduele geval, kan eonter onverenlgbaar zilJn met de efflclenste oplossing voor de verdelling van risico's en aansorakelljkheld met het $\infty \mathrm{g}$ op een zo goedkoop magelljke preventle en dekkling van schade voor en hele 
Klasse wan gevallen. Welgert men echter on an een met het oog daarop vastgestelde regel met betrekking tot risloo of aansprakeIIJkheld wast te houden in het concrete geval. ondat het das io onblliljk zou zlJn, dan wordt de voorspelbathela wan ansprakeIIJheld en risloo's een moellijke cogave. Mlen zal zloh (voor alle zekerheld) hoe dain ook verzekeren en andere preventleve maztrogelen treffen; alle achteraf overbodig of althans matuschapollik gezlen te duur zlJn. Het betoog gerloht op de stelling van het bljzonder karakter van privaatrecht is tenslatte ook daarom moellljk asnvaardbaar, omdat ult onderzoek blljkt dat ook in processen mesta filnancleel krachtige, goed georganiseerde elsers stam tegenover flnanclleel welnig sterke Indivlduen (16). Deze laatsten heben mestal weel meer aan harde, duldelljke regels dan an boterzacht quasi-ethlsch recht, dat door financleel on organlsator lsch krachtlger partijen in thet algemeen beter beinvloed kan worden (17).

Exit, wat mij betreft althans, het verhall over het bljzonder karakter wan het privaatrecht, dat ontwikkelling door wetgeving op grate schaall nlet goed zou verdragen. MIIn schets van het collectlef onbewuste van de pu" vatist, is vanzelfsprekend een karlkatuur, a is men zou menen, dat er privatisten zijn die konsekwent aan deze opvattlingen vasthouden. Maar elementen ervan komt men zeer geregeid tegen, bljwoorbeeld blj en over codiflcatle over lgens zeer genuanceerd denkend figuur is Schoordljk. Tegen Meljers" betoog voor een herzlening van het verblntenlssenrecht verwljst hl] met instemming naer Scholten: Aan een codificatle dlent grondige studle vooraf te gaan. Een modern boek over verbinten issenrecht moet nog gescrreven worden" (18). Merkwaardig genoeg vond Scholten ochter julist het verbintenissenrecht wel rlip voor codificatle. Soholten wordt in zoverre dan ook door schoordljk bekrltilseerd.

De commotie rond het. NEW is milns inzlens in belangr ljke mate te verklaren op grond van het simpele felt, dat het onderwerpen betreft waar zowel de belangrllke Jur Idlsche beroepsgroepen ls de rechtsgleleerden, traditioneel veel aandacht aan besteden. Het is een prachtig strljoberk voor Intellectuele en Ideologische gehillen wermengd met banale belangentegerstellingen, alles met de sug- 
gestle - vanzelfsrekend - dat het om maatschapell Jk bultengewoon betangr Ijke zaken gaat. Ik kan in alt verband nlet nalaten hier een mljne inzlens beschelden en reallistische mondel Inge ultoraak van

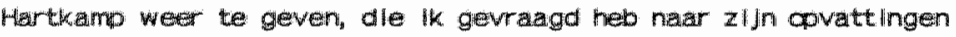
over het rut vali het Nleww Burger II lk Wetboek. HIJ antwoordde daarop dat lill het voornamellyk zag als het het oprulmen van de jur ldische gereedschapskist"; howel dit natuurllJk ook een "understatement is war de auteur wan de regellng van de algemene voor waarden. Als algemene typering wan het recht aan het NBW IIJkt het mil echter wel redelljk oo 2ljin plats.

Een dell van de weerstand tegen het NBW komt milnsi lnzliens eenvoudig voort ult het felt, dat men geen behoefte heeft aan oorulming van de gereedschapskist. Om duidelljk te maken warom dat zoveel weerstand kan oproepen, wll lk de volgende vergelljking maken. Sommlge mensen hebben onultroelbare nelg/ng a werkend een glgant lsche rotzool in hun studeerkamer te crecren. Meljers, een bultengewoon systematische geest, behoorde tot dat type. Meljers kon zloh dle luxe permitteren, want hlj kon fellloos ult de door hem geschapen chaos leder gewenst paperasje trekken, en van $z$ In vele in $\mathrm{m}$ In ogen zeer benlldenswaardige elgenschappen. Stel nu dat lemand anders coruiming houdt in een dergelljk kamer en alles keurlg op ewentueel nog Intelligent geordende stapeltjes: legt, dan is de ellende voor lsnog nlet te overzlen. De oude chacs waarmee men zo vertrouwd was (Scholten noemde het $\mathrm{BW}$ ien oud vertrouwd huls'), is vervangen doo een vooralsnog onbekende orde. Geen wonder dat men ach en wee zal roepen over de onzekerheld dile ontstalt bIJ de Invoering van het NBW. Is dle gedachte dan zo ult de lueht gegrepen? Ja an nee. Discussles over problemen met het NBW gadin in het huldige stadlum elgenlllk nog zelden over kwesties, dle naar huld lg recht wel duldellJk IIggen, maar In het NIBW nlet. Wel is het 20 , dat het NBW velle nleuwe vragen oproeot, watan zelfs nlet gedacht is. Tegenstanders van het NBW suggereren ulteraard, dat dvocaten stan te trappelen van verlangen on over die kwestles processen te gaan voeren (19). Dat $\| 1 j k t$ mul vrlJ onwaarschljollJk, a l was het maar omdat partljen in het algemeen net geinteresserd ziln in de beslechting van Juridische disputen. 
mazar alleen in de gevolgen van de ultsilg ervan. On d le reden zullen ze confllcten over onvoorspelbare aflooende rechick westies in het algemeen zoveel mogellik vermljoen. voor zover ochter nlew rechtsproblemen op de rechterstafel zullen worcen georeserteerd, is dat geenszins alleen negatlef te waarderen. Dlt kan Immers zeer stimulerend zlJn woor de rechtsontwlkkellng. De scheoping wan nleuwe rechtswragen door hercodiflcatle kan geenszins alleen is een nadeel ervan worden beschouwd ( 20$)$.

Een hell andere wraag warover IK mil wooralsnog bil gebrek aan deskundlgheld geen cordeel kan permitteren, is het of het NBW, zOals het $z$ lch in de loop van de vele tllent len Jaren ontwikkeld heef $t$, wel zo'n geslasgd product van wetgeving genoemd kan worden of anders geformulerd, of de gereedschapsikist wel op en zo verstandige manler is opgerulind. Dat is een ikwestle, die ochter losstaat van de vraag of een hercodiflcatle wan privatrecht oo zlohgenomen wenselljkk, zinvol en ultvoerbar kan zljn. Zelfs als dat zo Is, dan hebben we daarmee nog steeds nlet verk laard hoe hot in 1947 tot de codracht tot hercodiflcatle aan Mellers is gekomen. Dat was Immers om eerder ulteengezette redenen een onwaarschllinllJke gobeurtenlis in het lloht wan de globale rechibontwlikkellng op het terreln van het privaatrecht.

6 Het ontstaan wan het NBW a is een samenlocp wan onstandigheden.

Waarom werd in 1947 aan Meljers de codracht tot hercodiflcatle verleench Er zun drle wragen:

1 Waarom was Meljers zo geinteresseerd in heroodif lcatlle?

2 Waarom was de politiek bereld om op dat moment de opdracht te wer lenen?

3 Waarom heeft de hercodifleatle zo veselljk veel tijd in beslag genomen?

Over deze laatste vraag wil Ik maar heel weinig zeggen. Het ls een van de belangrlJke wragen dle onderdeel is wan onderzoek over ontstaan en ontw lkkelling van net Nleuw Burgerll Jk Wetboek waaraan Ik rulm een Jaar geleden mee begonnen ben, daartoe In staat gesteld 
doordat de faculteit mil den onder zoeksmedewerker ter beschlkking heeft gesteld en het Mnisterle wain justltle $z^{\prime} n$ zeer gewaardeorde medewerking heeft velend.

De verllening vin de codracht tot heroolf lcatle an Meljers In 1947 ls in zoverre merkindiardlg, dat op dat moment het thele land nog min of meer oo zllin gat lag ls gevolg van de Tweede werelooorlog. Hoe kwam men er blj om oo dat moment een opdracht te gieven voor lets cat van ult het gezlohtspunt van de wedercobouw van de samenleving op een nleuwe grondslag toch nlet all te weel om het IIf zou kurinen nebben, een codracht bovendlen dle ultdrukkellik een eerder technisch-Jurldisch karakter had? De verlening wan de opdracht kan ook verbazingwekkend genoemd worden in het llicht van het felt, dat tot voor de corlog de gedachte van een algemene hercodlf lcatle geen brede ondersteuning genoten had. Daarbl॥ moet over lgers a angetekend worden, dat het gangbare beeld dat men tot aan de Tweode Wereldoorlog vam algehele hercodif lcatle nlets wllde weten, met ultzonder Ing wan Mel Hers, zeer overdreven Is. Meljers zelf heeft over dat onderwerp geschreven in het Gedenkboek BW en ImIJn medewerker $\mathrm{mr}$. $E_{\text {* }}$ Florljn, zal ijs en weder dlenende, over enlge tijd eer publlcatle over alt onderwerp het llicht doen zlen (21).

Het flline van de achtergronden van de codrachtver lenling weet $k k$ na groot aantal intervlews met mensen dle blj het ontstaan en de ontw Ikkeling wan het. NBW betrokkenen zilln geweest, nog steeds niet. Wlersma beweert (22) dat het Illd van de Eerste Kamer, de VVDer Zegering-Hadders, dlle de vragen gesteld heeft naar aanlelding waarvan minister van Justitile Van Maarseveen in well willende overweolng nam om MelJers de opdracht te verlenen, hem verteld heeft dat zljn fractlegenoot Molenaar, die normallter de woordvoerder voor Justitle was voor de VVD, hem tevoren een dr letal onderwerpen had opgegeven. waarvan hil naar gelang er tijd woor was een of meer ter sprake zou kunnen brengen. Zeger Ing-Hadders had toen besloten om ultslultend de vragg te stellen omtrent de wenselljkheld van de herzlening van het NBW, omdat dle hem de belangrljkste leek. Dok Zegering-Hadders was, zo W lersma, zeer verrast geweest dat de mlnister direct zo posit lef daarop reageerde. Wlersma voegt daaraan 
toe, dat Zeger Ing-Hadders over voorafgeand overleg tussen de mintster en zIJn fractlegenoot Molenar nlets bekend was. Warma verKlaant de verlenling van de codracht as volgt. In de eerste plats wilst hil erop dat het bewr ljolngsootimisme nog nlet helemal woorblj was en dat de tljd dadrom gunstig was woor vernleuwingen. wooral als die niet direct grote ultgaven zouden medrengen. Voor justltile was het toen bovendien een zware tiljd door de igemene onvrede over de bljzondere rechtoraak. Geen wonder, aldus w lersna, dat de minister graag Inglng op een zo posttef en zo onverdacht vernlewwing brengend woorstel. Het NBW had derly We a we Whana mogen geloven, een zekere symbol lsche beteken ls van even nllow begin bulten de strikte context van het prlyaatreciht. Die symbollsche beteken's werd volgens wlersm versterkt door het felt, dit de opdracht a an MelJers ver leend wera. De gebeurten Issen rand het ontsiag var MelJers In 1940 en zilln behouden terugker ult de concentratlekampen, hadden Meljers namelljk en bekendheld gegeven blJ net grote publliek. HIJ symbollseerde tot co zekere hoogte persconlljk het verzet tegen en de overwinning op de Dultsersi. Een andere mogelljke factor, die met de corlog verband houdt, wordt door wlersma nlet direct gencema. Meljers schljnt net als zlljn medewerker J. Drlion, dle ven voraanstande rol In het verzet gespeld had, een 'hard-IIner' gewe te zll.jn wat betreft zlln standpunt over de bljzondere rechtspraak en zilj schllnen dat ook nlet onder stoelen of banken gestoken te hebben. Mogell Jk hoopte men in Den Haag dat de verlening van de opdracht tot hercodif lcatle ertoe kon lelden, dat Meljers het ministerle wat minder op de huld zou gaan zitten lin verband met de bljzondere rechtspraak (23).

Een factor war W lersme wel 00 wlist is het folt dat Meljers al heel lang voor heroodif lcatle geslelt had, dst hil on grote linternatlonale wetenschappellJke reputatle genoot en over on orine historische en rechtsvergulljkende kennis beschlkte. De gosdkoupte van de onderneming hing daar nauk mesamen. Meljers nam de tak

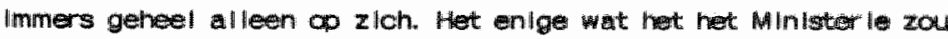
bekostigen was sen secretaresse en het vervoer van Maljer thessen Leiden en Den Hag. Tenslotte wijst Wlersma ter verklaring van do verlening van de apdracht op het felt, dat men destljcks do omwang 
van de onderneming sterk onderschet heeft. Mede gezlen zijn loeftijd ls het asnnemelljk dat Meljers gedacht moet hebben de klus in weing med dan tler Jaren te kunhen klaren. Over lgens kan men er over peculteren of Meljers, als hll langere tljo wan leven had ge-

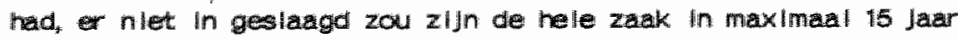
geheel af te ronden. BlJ $z$ lun overlljder In Junl 1954 waren de ontwerpen wan de erste vier boeken gepulbllceerd, boek wilf was eveneens voltoold, ter will de teksten van de andere boeken grotendes ger waren, met ultzonder ing van boek acht, dat his had Ultbeste an de subcomm issie Handelsrecht van de Staatscommissie voor de Burgerllike Wetgeving. Gesteld dat Mellers verder had kunnen blliven ootreden is regeringscommlssarls dan zou de weerstand In het parlement vermodelljk abinzlenlljk geringer geweest $z$ IJn dankzij MelJers' grote gezag. Of het resultaat dan erg bevredigend zou zIJn geweest, daarover zullen met name de latere bewerkers van het NBW zeker hun tw ll Jfels hebben, maar dat is een andere kwestle dan de vraag of Meljers nu werlkelljk zo vreselljk vel te optimistisch geweest is.

Wat Wlersma merkwaardig genoeg nlet vermelut, Us dat Molenaar, die zlch door Zeger Ing-Hadders llet vervangen, hoogleraar arbeldsrecht te Lelden was, dus een directe collega van Mellers. Het is daarom Interessant om na te gaan hoe de directe omgeving wan Melfers te Lellden de verlening van de opdracht aan Meljers gezlen heeft. Meljers' Virlend en voormallge Amsterdamse hulsgenoot Van a ven, deelt mee dat hly zich meent te herinneren dat Meljers al voor 1910 en schrlftje bljhleld met aantekeningen voor een NBW (24). Clever linga verwljst (25) naar deze oomerking wan van Oven, warwoor llk overlgens nergens en bevestigling voor heb kunnen vinden, en voegt daardin toe, dat Meljers bu dle aantekening "nlet enkel om de rechtsverbetering (ging), mar mede om de mogelljkheld van ede-

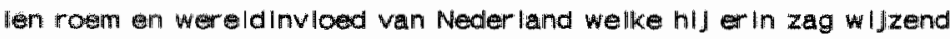
op wat frankr IJk met ziln code clvil hleraain had gewonnen en woorts o de lokkende en loffelljke voorbeelden van $Z$ wltserland en de Seandinavlsohe landen. Nhet slechts om zIJn kunde maar mede om deze met wolharding ultgedragen owertulging is het terecht geweest, dat men Juist hem de stift heeft toevertrouwd walarmee de nleuwe geboden 
in wetstafelen zouden worden gegrlft. Deze hoogdravende toevoe ging ontleende clever Unga niet aan Van oven. Wellloht echter wel aen de pede die MelJers in 1922 als voorzltter wan de Nederlandse Juristemwerenlging gehouden heeft over "de verhouding tussen rechter en metgever bul de recintsvorming' (26). Daarlin zegt lifi: "KHelne landen kunnen $z$ lch even goed als de machtigste staten door de voortreffell lkheld wan hun recht onderschelden. Mar als men plotselling op het gebled wan het recht een staat is $Z$ whltserland naar voren treden zlet, dan nevemt het dle lelding nlet door zljn rechtorazk, maar door de ver Jongling van zijh wetgevling. Oo gelljke Wijze zlin thans de Scandinavlsche landen bezlg, door in gemeenschappellike wetten het ganse burgerlljke reot opnleuw te regellen, zIch een plaats In de Europese rechtswetenschap te veroveren dle het voordlen noolt gehad heeft.' Men howeft er muns Inzlens met aan te twijfelen dat Meljers $z$ lch bewust was van zun rang a is Internationaal rechtsgeleerde en dat hll de noop koesterde dat een NBW hem oo gell Jke voet van beroemaheld (27) zou kurnen brengen met lemand als de codiflcator van het zwitsers pr Waatrecht, Huber.

Interessant in verband met MelJers' bewering dat kleine landen zlch even goed als de machtigste staten door de voortreffelljkhe lid van hun recht kumnen onderschelden, Is dat hier een ldee wordt aangesproken dat ook is aan te treffen bij eely ance grote Leldenaar uit deze euw, dle wellloht nog derder dan Paul Scholten en wellicht ook als evenkinle van Meljers tot de grootste valn onze juristen gerekend kan worden. Ik heb het hier over Van vollenhoven, met wle Mel Jers goed bewrliend is geweest. Van Vollenhoven, over wle IK elders geschreven heb (28), had eveneens het Idee dat hlJ vla de rechtswetenschap lets zou kunnen doen abn het hergtel wan Nersiands zevent lende euwse glor le. Van Vollenhoven heeft $z$ lch org Ingerpen-

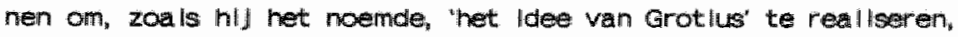
dat wll zeggen de ultbannling van de aamvilsoorlog wen door te streven naar de totstandkoming van verdragen ter oor lichting van oen Internationale vredesmacktt. Cok Van Vollenhovens Indrukwekkende werk over het adatrect stond In het teken wan de Inlossing wan een historlscile verpllchting, "de ereschuld" van de kolonlalle wantoestanden in Neder lands-I ndile aanger licht, dile hll. alshog hoopte te 
kunnen corplgeren in de rlloting van een 'hapoy' end van geleldeIfllke ontvoogding ven verzelfstandlighn. Ook Meljers heeft een bulterigewoon grote bewondering en belangstelling gehad woor Grotlus. Af In ziJn proefschrlft van 1900 noemt hll hugo de Groot (pag. 130) 'het schltterend vernuft dat het eerste natuurriecht los van scholastische ovvatingen ontwiklikeld heeft'. In het: boek wan Meljers advocate tljdens de corlog, Mw. Van Thallingen-Dols, 'De strljd om een mensenleven" is op te maken dat Meljers zlon nog tijdens zijn In- terner Ing in Barneveld heeft bezlg gehouden met Hugo de Groot. Meljers' collega Van Eysinga, die als zljn vertrouwensman cptrad, bevelt haar namelljk aan blj haar bezoek aan Meljers in Earnevield 2 lin werschlllende editles van Grotlus aldaar te bewonderen (29). Na de oorlog theeft Mellers samen met zilnn collega Fisher en de Zweed DovrIng, de ontdekker wan het Lundse handschrlft, de Hnlelding tot de Hollandse Rechtsgeleerdheld opnleuw ultgegeven. Meljers vond daarvoor kennell kk nog tijd naast zlJn werk aan het ontwerp van het: NBW.

Deze speculatles over romant lsche motleven blj leden van de Leldse Jurldische facultelt zouden nog aardiger zlin, alls er invloeden van Hugo de Groot te bespeuren zouden $z$ IJn in het NBW. De Smidt heeft aan dle vraag een beschouwing gewiljd (30) en lhif vond Inderdaad een aantal Interessante, zll het schaarse sporen van De Groot. In het $N B W$ die over lgens nlet van erg fundamentele beteken is zlln. Meljers vermeldt In zlln Algemene Inlelding (pag. 16) van zIJn ontwerp-NBW, dat de Indelling In zaken-en verbinten issenrecht ontleend is aan Hugo de Groot. Daaraan kan er echter nlet all te veel beteken is mechten, omdat zoa is Meljers zelf zegt, dlt onderocheild al bepallend was voor het nuldige Burger lljk wetboek. Oly (3i) heft gewezen op het felt, dat Meljers de term 'goederen' in dezelfde betekenis heeft gebrulkt a is Hugo de Groot en well a is allgemene anduliding van vermogensbestanddelen. De term 'zaak' echter heft Meljers duldelljk nlet overgenomen van Hugo de Groot, amdat hlJ grote bezwaren had tegen dlens onderscheld wan llichamelijke en onllohamelljke zaken. Mel Jers zo aanstootgevende omdraalling van de terminologle van "zaken" en "goederen" heeft dus nlettemin gedeeltelljk en eerbledwaadige histor ische achtergrond! 
Wat or ok zil van onze hypothese over Lelidse romantlek in relatie tot De Groot, Mellers alls persoon past er ultstekend in. Was hIJ immers nlet zeif In ballingschap geweet en symbollseerde de oorlogsgeschledenls rond zijn persoon nlet Hollends weerstands- en wedercpstandingsvermogen, alsmede de bereldheld wan en wezenlljk llbera denkend land $z$ lch te verzetten tegen trannte en rasclsme? In dlt verband $\mathrm{kIIIIgt}$ ook een overlgens al even speculdutlef art lkel van Boukema (32) enlg rellef, waarin hll suggerent det Meljers Jurla lsch denken In sterke mate geinspireerd zou ziln geweest door de flllosofie van Spinoza. Solnoza hoorde tot hetzelf de ' $\mathrm{V} / \mathrm{Jz}$ Innlg' ingestelle kamo in de tegenstellingen in de Republlek der verenigde Nederlanden a is Hugo de Groot.

\section{Meljers een milskend erkend genle.}

A is $U$ in muljn speculatles over verborgen motleven achter de ambltles van Meljers en zlJn ongewing In relatle tot het NBW, beluistert dat Ik dle ambities alleen maar zle als ulting van grootheldswaanzin, dan heeft $U$ het mis. Zelfs al zouden miljn soeculatles een grond van waarheld hebben, wat dan nog? zoais Talleyerand reeds zel: "de la grandeur au ridicule, ca n'est qu'un pas'. Waarom zou lemand dle beseft een groot rechtsgeleerde te zIJn bescheiden moeten zlijn in zljn amblties? Ik kan Meljers prestatles ulteraard alleen maar in zeer beperkte mate becordelen. De studile van zi.jn methodologische geschriften heeft $\mathrm{mll}$ echter ervan overtulga, dat MelJers geplaatst in zlJn tlJd, Inderdaad een genle kan worden genoemd. Een ultwoerige verdediging van dle conclusle, kan Ik hier niet geven en Ik verwils daarwoor nogmaals naw een latere publlcatle. Een oppervlakklge Indruk van thet genle van Meljers kriljat U over lgens door de nagedachten lsrede van Clever Inga te lezen. Het hoogt merkwaardlge is nu echter, dat het genle van Meljers tljdens zl.jn leven wellswaar werd erkend, maar kennelljk toch maar in beperkte mate begrepen. Zo schrlJft LangemelJer in 1960 : 'Over welnlg dingen, mlisschlen over nlets anders, zullen Nederlandise Juristen het zo gemakkelljk ens zljn als daarover, dat Meljers onder hen de 


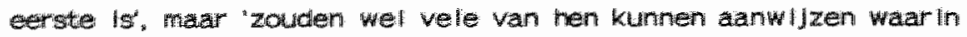
Julgt zlin onvergelljke beteken is gellegen?". Rum 25 laar later bllken "Acht ciwlisten In burger" - ik verwis nu naar de bljzonder interessante gelliknamlge Jublleumbundel van het Neder lands Juristentad van 1977 - $\infty$ dlle wrag nog stededs geen antwoord te kunnen geven. Dit is des te opvallender angezlen viff van die acht clvllisten bil Mel Jers georomoveerd zlJn. Een wan hen is Langemeyer zelf, dle zloh in 1977 als wolgt ultaat: "Ik was a is leerling nlet 20 wresellk getmooneerd door Meljers, maar een gevoel van teleurstelling heb Ik or nlet blJ gehad. Ik ben doodeenvoudig braaf bluven gelowen: hil zall inderdaad wel zo knap zllin als ledereen zegt: Met de them typerende bescheldenheld voegt hIJ daar dan nog aan toe: "Nog oo dit ogenblik ben $\mathrm{ik}$ ervan overtulgd dat het eenvoudig aian mil ligt dat $k K$ zin groothelid nlet heb gezlen. Absoluut! Ik heb nog altljd geen neiging om te denken dat Ik Meljers doorzlen heb en de andere mensen hem te hoog hebben gesteld, hele maal niet. lk denk eenvoullg dat het een soort groothell was war Ik weinig orgaan voor had". Opvallend is dat ook geen van de andere vier clvllisten dle blj Meljers gepromoveerd $z$ Ifn veel meer posltlefs over Meljers weten te zeggen dan dat hll zo veelzlldig was, een bultengewoon scherp verstand en geheugen had en over een fantast Ische werkkracht beschlkte. Ik vrees dat Ik Langemeljer gelljk moet geven in $z$ IJn zelfobservatie, en dat hil. mogell.jk Inderdaad weinig orgaan had woor het scort grootheld dat Meljers elgen was. Langemeljer had eerder; in zl In recensiles wan Meljers' methodologische geschrlften in 1950 en 1958 (33) wel degelljk onderkend dat Meljers' alssertatle van 1903 een hoogst orglneel en radlcaal de masque was var de in het blyzonder door de Jongere Jher ing gepropagerde gedechte, dat de begripsanalyse in de rechtsclogmatlek op zlchatif voldoende zou kunnen ziln on op productleve wiJze nleuwe rechtsvoorschrlften af te lelden ("BegriffsJurlsprudenz"). "Het is de moelte ward" zegt Langemeljer in 1958, "dit allies in Meljers' dissertatle dle na en have euw zo weinig dateert, te herlezen .... Wat treft is dan colk die met een voor Meljers karakter istleke herhalling telkens weer naar voren tredende afw|jzing van theorleen dle aan het recht en als thet ware spontane, een 'organlsche' ont- 
wikkeling wllien toeschrlJwen. Verwolgens maakt Langemeljer en opmerking, die toch zeer tot naderken zou hebben moeten stemmen: "Een princlpible tegenstelling zal men hiler ook kunnen zlen met ziJn wriend en medewerker on tal van gebleden, met wie hil steeds zo weinig mogelljk heeft gepalem lseerd, met scholten". Kennelljk is de gedachte dat Scholten zlch nog nlet zou hebben losgematik wan het negentlende euwse rechtspos I I I I lsme woor Langemeljer zelf wat al te gewaagd, want hil voegt er onmiddellljk aan toe "Zo zer a is dit nallaten van polemlek van belde zljoien oen uiting vain IIn gevoel geweest Is, zo zeer is het voor onze wetenschap te betreuran. De tegenstelling in beglinsel, die men tussen Melljers en Scholten zou kunnen vinden, schijnt nlet onwerzoenlljk maar zeker kan men het gevoel hebben, dat het probleem hetwelk aan thet licht zou komen Indien men haar scherp zou stellen, een ultgangsount voor vruchtbare methodische onderzoek Ingen zou kunnem zijn:

De door Langemeljer beplelte scherpstelling en het vruchtbare onderzoek is echter ultgebleven, met een gedeeltelljke ultzondering. Drion heeft namelluk in 1975 (34) naar aanlelding wan het zojulst weergegeven cltaat en wat hly noemt "de karikatuur dle van Dunne van het denken van Meljers heeft gemaakt' "namelljk 'als de meest typlsche exponent van een pulur legisme", een vergelljkend onderzoek gledaan naar de wijze warop beide jur isten hebben gereageerd op de bekendste gevallen van in deze eeuw gereallseerde of verdedigde creatleve rechtspraak oo het gebled van het privaatrecht. Drion komt tot de volgende conclusle: "Wat betreft de ruime leer van de onrechtmatige daad, van de goede trouw en het contractenrecht, van de natuurll jke verbintenls zowel als wat betreft de aanvarding wan een algemene verrljk Ingsactle voor het geldende recht, stonden Scholten en Meljers an dezelfide kant. Inzake de flduclatre elgendomsoverdracht laat scholten de aangenomen maktschappelllke behoeften de doorslag geven nu de letter van de wet dat toelaat, terwlJI Meljers hler de geest van de wet zwaarder llaat wegen. Tenslotte staat Meljers op het gebled wan het m/sirulk van elgendomsiecht een ruimere opwatting voor dan scholten. Drlons conclusie is in meer dan een opzloht interessant. In de erste plaats, ondat blljkt dat Meljers methodologische opvattingen per 
sallo niwt meri of minder ruinte bleden aan de rechter dan dle van Scholten, zll het dat hun opvatingen nlet altija tot dezelfide resultuten zullen lelden. In de tweede plaats is het interessant te $z$ len dat scholten in het gevall van de flduclaire elgendom kennelljk veel betekenis hecht aan de letter van de wett in zoverre deze nlet In strljd met de door hem onderkende maatscherpoll jke behoef ten, terwlj MelJers een leglst genoend zou kunnen worden In dle $z$ lin, dat woor hem de bedoeling yain de wetgever van doorslaggevende betekenis is, maar wel een leglst, voor wle nlet de letter van de wet, maar de teleologle ervani doorslaggevend Is. Bovendlen, zo wll Ik daaraan toevoegen, is het geenszinsi $z o$, dat men hlerult een grotere gezagsgetrouwheld van MelJers in vergelljking tot Scholten mag aflelden. De gehechtheld aan de letter van de wet kan blj Scholten namelljk milt alleen interpretatle-verrulmend werken. In het. "Algemeen deel" wil Scholten blj dwingend recht meer gezag toekennen aan de letter wan de wet, omdat 'het gezag hler met klem soreekt' (35). Voor een groter gewlicht van de grammatlcale interpretatile in geval van dwingend recht, zou de rechtszekerheld, dat wll zeggen de bescherming van de burger, een goed argument zIJn. Maar dat is niet. het motlef voor Scholters apvatting, want dle wll zonder meer het gezag respcteren. Kennelljk was Scholten anders dan MelJers wan mening dat het gezag meer wordt gerespecteerd door zloh aan de letter van de wet te houden in plats van aan het doel ervan. Hlerbl) komt, en dat 19 het derde punt van belang, dat ult het verschll van mening tussen Scholten en Meljers ten aanzlen van het mustorulk van recht blljkt, dat Melljers meen abjectiverende benadering voorstaat van wat onder de bedoelling van de wetgever of de strek$k$ ling van de wet verstaan most worden. Scholten elst namelljk voor misbrulk van ilgendomsrecht; dat nabst het ontbreken van een redeIIjk belang opzet tot benadeling bestaat, terwljl Meljers ook misbrulk wll aannemen, telkens wanneer een te grote onevenredigheld bestat tussen het persoonll Jke belang dat men dlent en het belang van een ander, dat geschaad wordt. Dr Ion werpt verwalgens terecht de vramg op $_{\text {i }}$ of eventueel gesteld zou kunnen worden dat Meljers In zll Jn praktisch rechtsdogmatlsch werk in felte als een aanhanger van Scholtens rechtswindingsleer te werk ging. 
Orlon beantwoordt ale waag - terecht naw mijn mening - ontikenmend. HIJ typeert het verschil tussen Scholten en Meljers als wolgt: "Men zal wan scholten kunnen zegien dat hill bll rechtswo"wming, dus bly de ontwlkkeling yan het recht, hoofdzakellik denkt aan rechisworming door de rechter, terwill door Mellers rechtsvorming omvat zowel de ontw lkkeling van het recht door rechtsorakk als de leglslatleve rechtsvorming. Dat betekent dat woor Meljers in geval van gewenste rechisontwikkeling, veell sterker dan bl] Scholten, telkens de vraag cokomt of in het gegeven geval de rechtsvorming aan de rechter kan worden overgelaten dan wel zu. llever aan de wetgever moet worden toevertrouwd:. IK ben dat geheel eens met Drlon, maar nlettemin roept dit de vraag op of en in hoeverre de positle van MelJers dan wel die wan Scholten oo grond van zulver methodologische Inzlchten gerechtvaardigd is. Dle kwestle laat Drion elgenllJk bulten beschouwing. HIJ nelgt ertoe te stellen dat er sorake is van een "kunstmatlg geschapen tegenstelling". De tegenstell ing is ongetwljfeld geweldig opgeklopt en well op een manler die een bljna omgekerd beeld geeft van de werkellike methodologlsche tegenstelling tussen MelJers en Scholten. Dle tegenstellling is echter geenszins kunstmatig, zelfs al llepen Meljers en Scholten qua praktische ultkomsten in hun positleffechtell lke beschouw Ingen, nlet ver ulteen! In de reeds aangekondigde publloatle zal lk dat pogen aan te tonen. De vergelljkling Melljers-Scholten zal daar duidelijk ten gunste van Meljers blljken ult te vallen en en bevestiglng $z$ ljn van Langemeljers suggestle, dat Scholten in methom dologisch denken nog half in de negentlende euw stond. Scholtens ant:-leglsme kan bovendlen, anders dan dat wan Mel Jers dertig Jaar eerder, aangemerkt worden a is een schl jngevecht, omdat het fenomen waartegen hlJ zlch keerde, al mauwelljks meer bestond (36).

Waaraan refereert Dr lon met zijn stelling van een "kunstmatge" tegenstelling. Volgens Dr lon houdt de tegenstelling van Scholten contra Meljers nauw verband met een andere: de tegenstelling van en 'Amsterdamse school" tegenover een "Leldse school". Ondat ik in de Amsterdamse school in de leer ben gegaan, kan lk bevestligen dat er In Amsterdam door Pltio en ziln aanhang een soort wr lend/WlJandbeeld werd opgehangen tussen de progresslef geachte Amsterdamse 
ovvattingen, warvan de oorsprong bil Scholten gelocallseerd werd en de formillstisch-leglatische covatingen die geacht werden wellg te teren in Lelden en dle net name bil Meljers hun corsprong zouden winten. Zonder mIJ nw voor deze Amsterdinse misvatting verantwoordellik te voelen, Is het woor mll een bultengewoon Intellectueel genowen om nlet alleen blj te dragen aan de vernletiglng van het ldee, dat er sorake is geweest van een 'modern' Amsterdams recintsdenken en een "achter IIلjk" legisme in Lelden, maar om de splts in felte om te draalen. Naar miln Inzlcht was eerder scholten een leglst dar MelJers. Zoals gezegd zal $\mathrm{K}$ dle stelling In deze openbare les nawell kss verder onderbouwen, maar bll leven en wellzlJn zikl ik de gecorlgeorde balans binnenkort presenteren.

Her zal ik nu aandacht besteden aan de kraag hoe het scheve, ja ongekeerde beelid ontrent de verhouding van het methodologlsoh denken wan Scholten en Meljers heeft kunnen ontstaan. In dlle context moeten wil namelljk Inder daad de controwerse tussern de Amstrendame en de Leldse school plaatsen en gedeeltelljk ook de controverses rond het NBW. Dat laatste llgt ook voor de hand, aangezlen vanult de "Amsterdamse visled de hercodiflcatlepoging gezlen werd ais ant-Scholtenlaanse poging tot neolegisme vam de kant van Lelden onder lelding van Meljers. Gelljk bekend was scholten een tegenstander, zlj het oolk geen felle tegenstander, valn gligehele heroodif Icatle. De oorsprong van de tegenstelling Leliden-Amsterdam en de daarult voortwloelende vertekening van de verhouding tussen Meljers en Scholten, heeft heell weinlg ult te staan met hun theoretische denkbelden, maar heel veel met de "petite hilstolire" van de Neder landse pr Ivatrechtswereld en daarover walt wederon het nodlge te lezen In "Acht: clwllisten in burger".

\section{a De "petlte histolre" vain een grote controverse.}

De oorsprong van de controverse Ilgt vermoedelljk bl] de zogenaamde 'af falre-Scheltema'. Scheltema was, al In het begln van de twintiger Jaren, hoogleraar aan de Leldse Jumldische facultelt en op cen gegeven moment is scheltema geschelden van ziln vrouw. Meljers die nogal strlikt opvattingen gehad schllnt te hebben over moraal en 
fatsoen in het famllieleven, koos de partl! valn de vrouw wan Scheltema, mede naar aanlelding van molllyktheden over de ongang met de kinderen. Dit leldde ertoe dat Scheltema's positle in Leiden onmo gelljk werd en dat hij wertrok naar de Ansterdamse Jurldische fam cultelt. Scholten heeft toen nog geprobeerd te bemlddelen, maar kreeg van Meljers nul op het request. Het felt dat Scheltema toen reeds 110 was van de Staatscomm lssle voor de Burgerlilke Wetgeving heeft er toen weer toe geleld, dat Meljers pas wlak voor de oorlog. na het overlljden van Scheltema, lid vam die commissle kon worden. In 1925 is er en vacature In de Staatscommlssle en Mellers wordt dan gepasseerd ten gunste van Scholten, met ls of lciele reden dat Scholten wat ouder was. Het was echter een aantoonbare smoes. Men was er o het ministerle terecht van overtulgd, dat er onmogeHllke situatie zou ontstain als Scheltema en Meljers belden in de commissle zouden zitten. Dat Melliers nlet eerder tot wetgevend werk geroepen is, heeft hem volgens Kisch geweld gi gefirustreerd (37) en het verklaart voor een deel zlln felle kritliek op de staatscommissle In zijn beroemde "Het felloze deel' van 1928. Meljers heeft later In ZlJn bljorage an het "Gedenkboek BW" van 1938, Implliclet erkend, dat 'Het felloze deel' en in zekere mate unfalre krltlek was (38).

Dit was echter alleen het begin van de tegenstellinglen tussen Meljers en hoogleraren van de Amsterdamse facultelt. Een andere controverse van perscomllike aard ontstond na de porlog tussen Meljers en Pltlo, later een fell orltilcus van het NBW. Pltlo zelf spreekt hlerover in 'Acht clwillsten in burger' (39): "Het betrof een Joden-kwestle die in de oorlog gespeelid had waarin Ik nlets fout had gedaan, maar lintegendeel eem Jood had geholpen. Meljers was fout ingelloht en dacht dat ik het wol fout had gedaan en Meljers herzag noolt $z$ in mening. I k ben ervan overtulga dat hl later begrepen heeft dat hij zlch verglst heeft. Maar hij nam noolt lets terug, dat was Ultgesioten!" De achtergrond van dit conflict was het wolgende. Pltio had volgens Mellers gefungerd als 'standin' voor C.H.F. Polak, de latere minister van Justltile, dile in de orlog nlet a is bewerker in de "Schets van het burgerlljke recht" van Veegens-oppenhelm vermeld kon worden. Na de oor log weligerde 
Pitlo ecther on te ckernen, clat hill niet meer dan slechts een 'stund In' was geweest. Ik weet nlet of MelJers' oordeel over Pltlo al dan niet terecht was, maar lik kan mlJ nauwelljks voorstellen dat deze affalre Pltio's houding ten cozlohte van Meljers, ook als or Iticus van het NBW, nlet sterk beIrviced heeft (40). Volgens PItlo heeft deze affaire zljn posttle in de Neder landse rechtswereld geschaad, bilvoorbet doordat hll noolt ultgenodigd is lld te worden vam de redactie van WPNR.

Een andere verhouding alle allesbehalwe goed genoemd kon worden, was dle tussen Meljers en de Amsterdamse hoogleraar Klsch. Dok Klsch is en van de "Acht clvilisten ln Burger" waar In hlJ zegt over Meljers: "There has neve been much Hove lost between US' (41). Meljers en KIsch hebben elkaar beter leren kennen doordat ze twee Jaar samen in Westerbork en Thereslenstadt heblen moeten doorbrengen. De heren lagen elkaar dulidelljk nlet zo erg. Dat had watarschljnlljk mede te maken met hun verschlllende rollen tijdens de or log. $\mathrm{K}$ isch was Ill van de Joodse Raad, maar heeft a is een wan de weinlgen in de gaten gehad welke functle de raad In felte verwulde en heeft zlch daarom eruit teruggetrokken. Nog meer heeft Kisch zlch verworwen door het feit dat hiJ de zogenaamde Barneveldprotectle heeft gewelgerd. In Barneveld werd een groep 'Ehrenjudlen' geconcentreerd, mensen dle zlch verdlenstell Jk hadden gemaakt voor Nederland, In het blljzonder In kunst en wetenschap. KISch, een vooraanstaand flguur In de Nederlandse Zlonlstische beweging, was de enlge dlle bereld was afstand te doen van de - zoals hlJ zegt'mII toegedachte gunst' en dle bereld was 'het lot te dellen' van de bevolk.Ingsgroep waartoe "hlJ de eer had te behoren". MIn of meer toevallig en bulten zilln toedoen om kreeg Klsch nlettemln Barmevelo-protectle, hoewel hlJ in Amsterdam kon blljwen. Daarmee was Kisch "Errenjude" In wen andere $z$ lin dan de rest van de Barneveld-groep. Mellers wordt; zodra hilj in Thereslenstadt arriveert, ogenbllkkell jk lld van de zogenaamde 'Altestenrat', dat wII zeggen het kampbestuur, woor zover dat aan de gevangenen zelf werd overgeIaten. Dle positle dankte hlJ aan de bemiddeling van zlun advocate, mevrouw Van Thallingen-Dols, dle blj haar pogingen Meljers te laten emigreren tot in hoge kringen te Berlljn connectles haid aange- 
knoopt. In de sfeer van en concentratlekamo maken zulke oonnectles mensen vanzelfsprekend mlet drect pooulalr. Overlgens bewert Kisch nergens dat Meljers zlah nlet voortreffellyk gedragen zou hebben In dile bultengewoon maelllyke positle wan lla van de "Altestenrat". HIJ maakt hem bovendlen een uitdrukkelljk comp/iment voor de wljze "waarmee hl] zlch, onder overwinning van grote moellijkheden, ais het overschrljoden van de Russisch-Amer lkaanse demarcatlellun, In hoedanligheld van lelder van de Nederlandse groep (uit Thereslenstadt) van dle functle neeft gekweten: Mel Jers opvatt ingen over KIsch, waren ook nilet bultenglewoon positlef, en wel om redenen dle $\mathrm{lk}$ nlet kan releveren, omdat $\mathrm{k} \mathrm{k} \mathrm{m} / \mathrm{J}$ n openbare les nlet helemaal tot het niveau van tv-pr Iwe wil verheffen, hoe aantrekke$11 \mathrm{Jk}$ sommige toehoorders dat ongetw If feld ook zouden vinden. In 1955 publliceert Kisch een werkellijk moordende krltiek oo de Inleldende titel van het NBW, dle er volgens Abas de nekslag voor is geweest (42). Was dat falre kritlek? Naar mijn mening nlet, ook al geloof $\mathrm{k}$ nlet, dat Kisch te kwader trouw is geweest in ziJn krltlek. Ik zal in mlin boven reeds eerder aangekondigde publlcatle: betogen, dat de krltlek van Klsch grotendeels berust op misverstand en onbekendheld met Meljers' methowolog ische geschrlften.

De vierde 'Amsterdammer' dle het werdlent In het kader van deze 'petlte histolre' van het NBW genoemd te worden, is Eggensi. Eggens werd voor de oorlog al algemeen erkend als een bljzonder knappe Jur Ist. Tevens stond hil echter bekend als een vrlJwel onmogelljk flgutur, die de meest vreselljke dingen kan zeggen. Het gevollg daarvan was dat Eggens inlet tot hoogleraar benoemd werd In Nederland en toen min of meer naar Batawla is ultgeweken. Nogal wat faam heeft Eggens $z$ lch in de oor log verworven als auteur van Londense beslultwetgeving. Niet verwonder li jk is dan dat Eggens na de oor log tot lid van de Staatsoommissle voor de Burgerlljke Wetgeving wordt benoemd en als zodanlg ook de ontwerpen van Mel Jers mee bespreekt. Nu waren Eggens' methodollogische covattingen, hiJ was Hegellaan, nogal verschlllend van dle van Meljers. ZIJn positle in de Staatucommissle was daardoor nlet erg gemakkelljk " en het werhaal gaat,

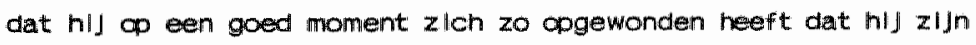
stoel heeft omgedraald en met de rug naar de rest van het gezell 
schep is gaan zitten. Over lgens schlint de persoonllike verhouding tussen Eggens an Melfers betrekkellgk goed geweest te zllin, zU het dat Eggers, dle volgens $P$ litlo nogal aan minder wardighelidscomplexen leed, zloh in zijn hart superleur woslde aan Neljers, hetgeen bllkt uit Egoens bekende ultsrakik: "Wat zou ik willen dat ik de hersens wan Meljers had, want ik zou nog mee kunnen denken ook' (43). Volgens Plto maakte Eggens ook in de collegezaal opmerk ingen a is: "Meljers heeft in ons land de rechtsbecefenlng 2000 laar te ruggeschroefd'. Men kan zlch woorstellen, diat er In het zogenaamde Drlemansctap Dr lon-Eggens-De Jong, dat MelJers na zilin over llJden is opgevolgd ais lelders van de hercodiflcatle, de nodige soanningen hebben geheerst, aangezlen zowel Drion als De Jong leerlingen en bewonderaars vari Mel jers waren. Beweerd wordt dan ook dat een woorname reden waarom Eggeins in 1958 ult het Orlemanschap is gestapt, was dat hil de amdere heren nlet bereld vond om de zlins Inzlens verfoellyke geslotenheid wan het stelsel van verbintenlssen oo te geven. In 1958 wertrekt Eggens natar de Amsterdamse facultelt en wel mede, naar diens zeggen, dankzll de bemlddellng van Pltlo (44). Naast Pltio zilln Schoordljk en Van Dunne belangrljke orltllol van het NBW geweest. Schoordljk is een leerllng van Eggens, Van Dunne is een leerling van Schoordljk en belde hechten grote betekenls aan de dla lectische opvattingen over rechtswinding dlle door Eggens gepropageerd werden. Tot zover de "pette histolre" dlie mijns Inzlens ten grondslag Ilgt aan de zogenaamde tegenstelIllng tussen de Amsterdamse en de Leldse school, alsmede aan veel van de kritlek op het NBW, ook al behoort die natuurlluk in princlpe ultsiultend oo z'n zakelljke merites beoordeeld te worden en kan hll zeker allesbehalve worden afgedaan met een beroep co de zo Julst gereleverde 'pet l te histolre'. Dat dle er nlets mee te maken zou hebben, IIJkt mll ochter een wat all te naleve gedachte. De "Detite histolre" heb ik cok inlet wergegeven om aan de kaak te stellen hoe schandelljk men zloh wel nlet gedragen heeft ten opzlohte vain Meljers en zlln geestesproducten. Ik kan helemaal nlet goed be cordelen wise in al dile persoonllike controverses gelljk had of nlet. Ik vind dat cok nlet wan zo vreselljk veel belang. verder kan men ook nllet van tevoren zeggen dat dit soort persoon persconilijke 
en ain Institutles als faculteften gebonden tegenstellingery noodzakellikerwils slechte ef fecten moeten hebben op de wetenschappow lljke ontwlkkeling. Haat, nijd en ambltle kunnen evenzeer lelden tot schone als verderfelljke resultaten in de wetensonap. Dat het In dlt geval erder negatlef ultgewerikt heeft, meen lk behalve door het felt dat er gedeeltell lik een valse tegenstell Ing tussen Scholten en Meljers gecreed is, zoals Drion heeft laten zlen, ook te kunnen aantonen een dantal andere punten.

Nlet alleen heeft Langemeljer heel duldelljk de aard wan Meljers" methodologlsch denken beschreven, maar hil heeft ook zeer terecint gesteld dat er een $\mathrm{Wr} \mid \downarrow$ direct verband moet $z$ ljn tussen Meljers" "Algemene begrlppen" en het NBW. Naar een studle hlew"over" zall men echter vergeefs zoeken (45), hoewel het al bl] een opperwillkk Ige kennisneming van de 'Algemene begripperi', door Meljers tiljidens de oorlog geschreven, volstrekt duldelijk wordt dat een heel nauw verband is tussen de opvattingen dle hll daar ulteenzet en zilln ontwerp voor het NBW.

Beha Ive Langemel Jers besprek Ingen en de relatie met het NBW, Is eir nog een derde reden waarom de geringe belangstelling voor MelJers' methodologische geschrlften merkwaardig is te achten. Dhe is gelegen in wat MelJers zelf over alle geschr/ften gezegd heeft. Het proefsch Ift 'Dogmatische rechtswetenschap', waarop Meljers in 1303 o 23-jarige leeftljd cum laude bif Houwing, tevens leermeester wam Schalten overlgens, is gepromoveerd, heeft woor zover Ik heb kunnen nagaan, In dle $t$ ljd geen enkele aandacht getrokken. Besprek Ingen of verwilla Ingen In literatuur van voor de oor log naar dat proefisch lfft komen nlet of nauwelliks voor. Ook Langemel jer constateert $\mathrm{kn} z \mathrm{ll} \mathrm{j} n$ belde recensles een bilina totaal gebrek aen belangstelling voor Meljers' methodologische geschriften. Scholten verwijgt in 2 iln "Algemeen deel' in het geheel nlet naar. Wat schllft Meljers echter IJskoud In het voorwoord van $z \|$ In 'Algemene begrlppen' van 1948 ? op het onderwerp wan zlun proefschrlft, de warde wan deducthe en Inductle voor begrlps en oordeelvorming in de rechtswetenschap, meent hil nlet terug te hoeven komen, kennell lk erwan overtulgd, dat $\mathrm{hl}$ J darover In 1900 al het def Inltleve woord gesproken heeft. HIJ vervolgt dan: "Behalve echter de in miln proefschlft 
besproken oorzaken van mlswerstand en dwaling in de leer der jurldische begrlppenwereld, bestaan er heden ten dage nog wele andere". Dat kan onder andiere Schotten dus in zIIn zak steken (46) Dat $z$ IJn eerste werk zo weinlg is gewazarderd, deert Meljers ogenschijnll.jk nlet en onversaagd zegt hlJ over de 'Algemene begrlppen': "Voor twintlg Jaren was alles nieuw. Ongetwlyfeld kan men enkele verwante gedachten in de latate tlla bly andere schrlfwers vinden. Mil is echter nlet bekend dat olt ook het geval is met de hoof dgedachten warop ditervolgende ulteenzettingen berustent. Meljers pretendeert der halwe wolstrekt unleke methodologle ontwikkeld te hebben thet magi verbazingwekkend heten dat als zo'n beroemd Jur lst dat beweert, alle mindere goden zlch nlet met gretlgheld oo $z$ In werk storten.

Langemeljer Is overlgens nlet de enlge dle zllch met Meljers" methodologische geschuften heeft bezlg gehouden. In 1971 verschlint Vain Dunness proefschr ift "Normatleve ultileg van rechtshandel Ingen", waar In deze fel van leer trekt tegen de zIJns Inzlens blina negentende-eeuwse leglst Meljers met name co het punt van diens covattingen over de wilsleer. Ik ben van mening dat Van Dumne, wlens geschrlften Ik overigens bultengewoon insolrerend vind, Mellers Inderdaad verkeerd beoordeeld heeft, met name cok $\infty$ het punt van Mellers' oovattingen over de grondslag van de rechtshandelling in het privalurecht, zoals cok al gesteld is door Van Schllfgaarde (47) en Nieuwenhuls (48). Hetzelfde Kan mijns Inzlens gezegd worden voor Van Dunnes" recentelijk gepubllceerde kritiek (49) op Meljers' oowatting van het begr ip zaak als ultsilultend betrekking hebbend op stoffelljkike woorwerpen. ZlJn bewering dat Melljers zlcih kennelljk nlet bewust is geweest van het onderscheld tussen een zaak a is stoffelljk voorwerp en het recht op zaak is milns inzlens aantoonbaar onjuist (50).

In 1975 schrijft Van Dunne's postdoctorale leermester Schoordiljk een biljzonder interessante beschouwing over de (herycodiflicatlegedachte bij Scholten on Meljers in het Scholten-nummer van WPNR. Schoordilk relat Iveert daar in sterke mate de gedachte dat Scholten zo tegen hercodiflcatlie geweest zou ziln. Scholten, zo Schoordilk, zag nlets in algehele hercodiflcatle, maar had geens- 
Zins oen van Meljers arg af wljkende oowatting over net belang wan wetgeving in het burger $11 \mathrm{Jk}$ recht. Meljers argumenten woor hercoulflcatle komen echter in schoordijks beschouwing wing mit de verf naar miln mening, hetgeen naturlijk wel enigszins begrljpoIIJk is in dit aan Scholten gewljoe nummer van WPNR. Schoordiljk relativeert ook op verscheldene platsen, de tegenstelling in fur ldisch denken tussen Scholten en Meljers vilj sterk, zelfs mede blj wijze van llchte krltlek oo Van Dumne's visle op Meljers w isthoorle van de recitshandeling. Toch komt de gedachte nlet blj Schoordilk oo, dat er lets fundamenteel mis zou kunnen zl.Jn met het beeld van de 'leglst" Meljers en de "antl-legist" Scholten. Mellers blift In Schoordilks wisle een exponent wan wat hl in navolging van zllin leermeester Eggens het "scheldende denken' noemt. Schoordijk construeert op basis van tamelijk magere indlcatles een " $\mathrm{w}$ iljdenkers'per lode tot ongeveer 1930 en en me legistische per lode daarna in thet denken van Meljers. Zonder dat hIl deze stelling nader ultwerkt, stelt Schoordljk, dat de "Algemene begrlowen" nlet "een brlljant siluitstuk" ziljn oo zlin ceuvre, mair "een corpus allenum In MelJers denker". Kortom: volgens Schoordlik was Mell Jers elgenlijk een Scholtenlaan in de becefening van de rechisologmatlek, zijn methodologlsche geschriften waren een schliofreen wanhangsell. Deze these staat natuur IIjk wel haaks op net voorwoord van de 'Allgemene begrippen; waar in Meljers de continutteit in ziln denken stelt. Ik denk dat MelJers dat goed zag. ZlJn cenken vertoont mulus Inzlens juist een bijna merkwaardig te noemen af wezlgheld var discontinuttelt en er is vermoedelljk weinig in zijn ceuvre aan te wilzen, dat onverenlgbaar Is met de oovattingen die hij in de "Algemene begr lippen' verdediga heeft.

In 1977 wordt door de verenlglng voor w ljsbegeente wain het recht het preadvles van A. de Roon behandeld, war in de methodologlsche opvattingen van Meljers worden behandeld. De Roon geeft een zeer correcte weergawe wan Mel Jers' betwer Ingen in 'Dogmatische rechtswo tenschap', dle hiJ blinnen net kader van wat hly "een emplirischInductleve benadering' noemt, kennellik aanvaardbaar acht. HIJ verwent echter ale benadering en wervolgt met en kritilek $\infty$ Meljers' covatting over het subjectleve necht, die weinig overtul- 
gerid lsenzl] men zlch op het standount wan de door De Roon aan-

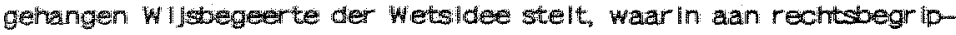
Den anders dan bll Meljers nlet dleen en zulwer systematlserende functle wordt toegekend. ondanks dle op zlchzelf valkomen correcte weergave, blijkt ult De Roons preadvles elgenllyk nauwell jks wat nu precles de orglnalleit van de dogmatische rechtswetenschap is en hoe zloh Meljers opvatting nu precles verhoudt tot concurrerende oprattingen, zod is bljwoorbeeld die van Scholten, de in Nederland toch nog steeds meest populalre rechtsmethodoloog."

Afgezlen wan het reeds genoemde artikel van Boukema, zijin er na 1977 bljaragen van Bloembergen (1980) (51) en Veegens (1982) (52) over MelJers' methodologlsche opvattingen verschenen. Beide blldraglen llggen In de 11 In van het betoog wan Drlon: de tegenstelling ten opzlchte van Scholten is zwaar overdreven, in felte wasi er nlet meer dan een accentverschll.

Aldus is naar miln menlng nog nauwell jks recht gedaan aan de verdlensten van Mellers' Inzichten op het terreln wan de Jur idische methodologle, nog afgezlen van hun beteken is woor een goed begr ip van het NBW, voorzover dat nog steeds gebaseerd us ap zijn antwempen. Een princlplele verdedigling op basis van onderzoek van Meljers' methodologlsche opvattingen, is nog nllet beproefd. Wat zlJin de verdlensten van MelJers' methodologische Ideeten dan? Ik kan daar hler maar zeer kort op Ingaam. Hoewel Boukema terecht op Whist, dat Meljers kennelljk alleen op de hoogte was van de klassleke, syllogistische logica en er zelfs nlet gleheel mee ult de voeten bleek te kunnen, had Meljers wel een uiterst heldere voorsitelling over de aard van de loglca, evena ls over de aard van semantische analyse. Scholtery daarentegen hleld onmiskenbaar en psychologlst/sche misvatting ten danzlen varl de loglca co na. BIJ Scholten hangt nog duldelljk allerlel essentialistisch gedachtengoed dat hem In zekere mate verwant maakt met het denken van de "Begr Iffsjurlsprudenz". Meljers is eenvoudig weel radicaler in zijn af wiljzing van de stelling. dat woorden op zlehze if duldellijk zouden kunnen ziJn. Aan de andere kant verleldt dit Meljers nlet tot het Idee dat opsporen van de betekenils waar in woorden zll jn gebrulkt, een subjectlef en noodzakelljkerwI js var de vooronderstell Ingen van 
de interpretant a harkellike aangelogenheld is. ook makt Meljers cen bultengewoon helder onderscheld tussen Interpretatle en analogle enerzljos, tussen de regellngsintentle en de betekenisintentie van de wetgever anderzljos. Daarbl] Is Meljers zlch overigens volkomen bewust van het felt, dat en veelhell wan interpretatlemarlaal bestaat dat werschlllende, mogell Jk tegenstrl Jdige Mypotheses over de beteken is van de wet mogelljk kan maken. Mheljers maakt verder een neel duldelilk onderscheld tussem de interpretatle volgens de regellngsintentle, volgens de betekenisintentie cin volgens. het grammaticale gebrulk. Mel Jers makkt cok een zeer vorhelider end onderscheld tussen rechtsregeis, rechtsbeginselen en rechtsbelangen. Daaraan vastknopend kan hiJ een onderscheld maken tussen de cp de betekenis intent le berustende wetsinterpretatile enerzijos, analogle dle aanslult bll de regelingsintentle van de wetgever en " $\mathrm{rlJe}$ rechtsworming;, dle berust oo de regellngsintenties wan een competent recintsorgaan, dat ulteraard wel aanslulting kan zceken blj in het positlef recht voorkomende regell ingsmot leven. Mel Jers toont ook overtulgend aan dat or in strlkte zin geen leemten kunnen ziln In en wet, maar wel onwolledigheden in het licht wan de regellngsintenties. Welke vrljheld de rechter bu de rechtsorming gelaten wordt, is volgens Meljers - en mijns inzlens terecht - nlet eem Kwestle van semantlek, maar een kwestle van staatstheoretische opvatting of, zoais Meljers dat noemde, doelmatighelldsoverwegingen. Mellers' voorkeur voor rechtsworming door de wetgever is prlmair bepaalid door het ldee dat het onwensellilk Is dat de rechter rechtsscheppend te werk gaat bulten het terrein van de zulvere toepassing en de analogle. Dit cordew zal denk Ik ledereen die In princlpe de solheldsiljn tussen polltilek en rechtspraak voorstat nog steveds ondersch llwen. Dit ls voor hem ook een belangr IJk argument geweest voor de heroodificatle (53).

Met deze korte andulding moet IIK volstian en woor het overige naar een latere publlicatle verwljzen. Laat IK in leder geval miln visie hier nog scherp proflleren ten cozlchte van de andere twee hler behandelde. I $k$ ben het noch eens met degenen die Mel Jers In methodolloglsch opzlicht woor een (eventueel schizofreen) legist versliften, noch met degenen dile nilet meer dan een accentversonil 
Wllen zlen tussen schotten en Mellers. Er is een heel wezenIIJk werschll tussen belde, dle grof (In de dubbele zln des woords) gezegd neerkomt op het felt, dat scholten bekentenisilteratuur is, terw II Meljers zlchzelf onderwerpen heeft aan en de gemlddelde Jurlst afsch Ikkende analyt lsche strenghelli. De reden warom dit laatste zo afschllikt zIJn door LangemelJer aangegeven. De eerste reden is het abstrictlenlveau van weel van Meljers thethodologische beschouw Ingen (54). De tweede reden verklaart well lcht, warom ook Langemeller zelf, zoals hl] gezegd heeft, "het orgaan mlst" voor Meljers' grootheld. Langemeljer zegt dat de gewone Jurlst 'blJ "algemene rechicsleer" meestal aan lets anders denkt dan Meljers daaronder verstaat. Gewoonlijk tooh vindt men de term gebrulkt woor een onderzoek naar de inhoud van dle begr lppen, waarvan de onderzoeker aanneemt, dat zlJ ult hoofde van het wezen van het recht noodzakelljk in elk rechtsstelsel en wel steeds met gelljke inhoud moeten voorkomen.. Meljers daarentegen bedoelt ermede ..... de leer van de begr lppen waarmede men cen aantal recihtsregels van bepaalde Inhoud .... het doelmatlgst kan ordenen' (55). Mel Jers denkwiljze verdraagt zlch nlet met het wat stichtelljk essentlallsme, waaraan zovele Juristen In leder geval in deze eeuw kennell llk zoveel behoefte hebben, een behoefte waaraan scholten bij ultstek tegemoet is gekomen.

9 Meljers en de (privaat)rechtsleer in de tweede helft wan deze eavw.

Heeft Meljers al alles gezegd wat er over rechtswinding in het privaatrecht te zeggen valt? Geensizins, maar, zoals Langemeljer zegt, men moet Meljers ook als klind wan zijn tijd zlen. Wat ook zij van tekortkomingen in Meijers methodologlsche gesch Iften, Ik meen dat deze door geen van zIJun tIJjgenoten gecompenseer z zl.Ju, en zeker nlet door Scholten. Op het terrein van begr lpsworming en systematlek ziJm Meljers' geschrlften miJns inzlens echter nog steeds "ongedateerd", om nog eens met Langemel jer te spreken.

Ingr IJpende vernleuwing in het rechtstheoret lsch denken heeft zlch, als we even afzlen van Hans Kelsen, dle overlgens eveneens 
een typlsch kind van de tujd wan Meljers is geweest (56). pas in de tweede helft van deze eeuw voorgedian en wel in de worm van de met name door Wittgenstein geinspliecerde analyt ische rechtsf llosof le, dile blil ons $z$ 'n vroege neerslag vond in het schitterende proefschrlft Van J.F. Glastra van Loon, 'Norm en handelling' (1956), waarwan thans gelukk.lg elndelljk en herdruk zal verschljnen. Dlt Is echter mijns inzlens al evenzeer, zil het op en andere wijze, miskend als het methodologisch werk van Meljers (zle onder), en dit schrljf lk mede co rekening wan de na de tweede wereldoorlog bulten proportles geraakte Scholten-cultus.

voor de oor log schilnt het 'Algemeen deel' met ultzondering van Eggens (57), nlet zoveel enthouslasme te hebben losgemaakt. Dat dit na de oorlog in zo sterke mate het geval is geweest, kan mijns inzlens verklaard worden, door het ethisch revell In de rechtsleer als gewolg van de Tweede Wereldoor log, In het bljzonder cok gestlmuleerd door Gustav Radbruch, dle het rechtspos/tivisme de sohuld In de schoenen schoof voor het felt, dat de Dultse Jur isten in het algemeen zo enthouslast met HItler c.s. gecollaboreerd hebben. Intussen is overlgens wel aangetoond, dat als er van de rechtsleer wat dit betreft al enlge Invloed is ultgegaan, veeleer anti-rechtsm positivistische stromingen verantwoordelljk ziln voor fascistische sympathleen onder Jurlisten (58). Hoe dan ook, in dle sfeer van na de oorlog is het begr Ijpell Jk, dat In Neder land, waar cok de nodige prominente Juristen boter op hun hoofd hadden, het "Algemeen deel" met: $z^{\prime} \cap$ nu bIJna dominee-achtig aandoende accent ap het geweten van de Jurist, geschreven bovendlen door lemand dle zlich In de oorlog voorbeeldig gedragen had, gemakkelljk Ingang vond. Voeg hlerbll de Invloed van de controverse "Leliden-Amsterdam" (59) en het is bogrljpelljk, dat methodologische opvattingen als dle van Meljers in het verdomhoekje van legisme en rechtsposit Ivisme terecht kwamen. Cok de receptle van het proefsctrift van Glastra van Loon heeft mulns Inzlens te lljden gehad wan de Scholtem-cultus. Wellswaar kreeg het en sympathleke ontvangst, maar voorzover het de rochtsw leer getnsplreerd heeft, is dat op wiJze geschled, warvan IK $\mathrm{m} \| \mathrm{J}$ ernstig afvraag of het de goedkeuring wan de auteur kon wegaragen (60). J. ter Helde heeft zllch namelljk voor zljn "functlonele 
rechteleer" o Glastra's covathingen als theoretische basis beroeDer. Of dat en terechte claim is is daarom zo moellijk na te gaan, omdat de functionele rechtsleer en theor etische polpourt is waar voor bllna elk wat wils kan worden aangletrof fen: existentiallsme, fenomenologle, hermeneutlek, retorica, speltheor lie, systeentheor he en wat nlet al (61). Daarbl) komt dat zulke fundamentele concepten ais thandellng', 'functlet en 'omgeving' door Tier Helde noolt precies zljn geclefinleerd en ultgewerkt. In het begln van de Jaren zeventig kan men dan het amusante tafereel gadeslaan, hoe de functlonallst Ter Helde, de existentlallst Wan Schellen en de dlalectlcus van Dunne met elkar in de cllnch gaan over de vraag. wle zlch de ware erfgenaam wan Scholten mag noemen (62). De ten opzlchte van scholten door Ter Helde geclaimde orginalltelt, komt hem volgens Van Dunne - terecht volgens Drion - nlet toe. Dat kan wederom bevorderd hebben, dat de potent lelle inspiratle van Glastra valn Loon's: "Norm en handellng" mlin of meer opgezogen is door de theoretische stof zulger van Ter Helde, waardoor Glastra van Loon met de functionele rechtsleer geldentiflceerd Is gaan worden. Ik meen IK dit kunnen aantonen aan de hand wan het volgende. In 1979 promoveert J.H. Nleuwenhuls te Lelden (63) oo het voortreffelljke "Drle beginselen vain contractenrecht". Hoewel diens beschouw Ingen millns Inzliens bljzonder goed aanslulten bly 'Norm en handeling', wordt naar dit laatste zelfs nlet verwezen. in plaats daarvan heeft Nleuwenhuls op een nogal dubleuze wiJze (64) aanslulting gezocht blf de taal handellingstheorle.

Afgezlen van Invloeden van de analyt lsche rechtstheorle, is er milns Inzlens op het terrein van de pr Wvatrechtsleer van na de twede wereldoorlog werkelljk welnig nleuws te melden. Stromlingen as de hermeneutlek, de dlalectlek e.d. hebben nlet geleld tot Jurlalische methodologle in en constructleve, theoretisch ultgeworkte zIn. Men kan ze nog het beste typeren als wormen van Jur ldische "Gesinnungsethlk', een typering dle ook al voor net werk van scholten opgaat. Het enlge miJns inzlens overlgens nogal zwakke (65) IlchtpuntJe, is de zogenaamde vergelljk Ingsmethode van W larda.

BiJ dit alles komt, dat de analytische handellingstheor le, zoals ontwikkeld door Glastra van Loon, duldelljke beperk $n$ gen heeft. 
Functles van recht zlln Immers nlet te reduceren to handelingsw Functles, dat will zeggen tot van symbollsche betekenlssen fhankIIJke intentles (nlet te verwarren met 'bewuste' intentles). Rechtsregels vervullen ook allerlel functles in het maatschacpelljk systeem, dle in zekere $z$ ln nevenwerkingen $z$ ll hn vain handelingen en dle soms alleen maar gereallserd kunnen worden, dankzlj het felt dat men dle nevenwerk Ingen nllet intendeert. Handellngstheorle is voor het prlvaatrecht, in het bljzonder woor rechtshandellingen. zeer verhelderend, hoewel geenszins voldoende om alle vragen rond confllcterende z in van han-del ingen op te lossen. Een deel van dle $z$ In is immers nlet milcro-, maar macro-soclaal bepaald en voor de oplossing van dle wragen zal men zeker aanslulting moeten zoeken bll soclale en economische macro-theorlesn over (priwaat)recht. In dit verband $w|l| k$ de aandacht vestigen op het felt, dat ondanks het Amsterdamse proefschrift van E.J.P. Mackaay van 1980 (66), de economische analyse van het recht in Nederland zo goed als nlet bestaat, hoewel dit met name ook woor het prlvaatrecht krachtige analytische linstrument elders af bljzonder ver ontwikkeld is.

Tensllotte wil ik nlet onvermeld laten, dat zlch tamelljk onafhankelljk vain nationale tradities, wel degelljk voorultgang heeft voorgedaam in de algemene rechtstheor le onder Invloed van de moderne loglca, de wetenschapstheorle en de taalfllosofle. Er zlln aanwijzingen, dat deze voorultgang thans oolk in de rechtsologmatlek merkbaar begint te worden (67). Dat neemt echter nlet weg, dat de scholten-cultus ertoe geleld heeft, dat op het terrelin van de rechitsleer wel veel varlatle, maar bar welnig selectle heeft plaatsgevonden. Er Is geen sprake geweest van enlge vorm van construct leve theoret Ische woorultgang. Waren Mel Jers methodologlsche geschriften en wooral zilln strak analytische, precleze stijl van methodolog ische denken, nlet dermate in het verdomhoek je gep laatst, dan is het denkbaar dat de ontw lkkelling $z$ lch op een veel productlevere ljze had kunnen voltrekken.

10 De verhouding van wetgever en rechter..

Tot slot wan deze openbare les wll Ik terug komen op de kwestle van 
de verhouding van wetgever en rechiter. Boven is all vaker gesteld, dat de privaturechtsleer gebukt is gegaan onder de vermenging van interpretatlekwestles met staatstheoretische vraagstukken. Houdt men vast aan de ons staacsbestell ten grondslag Ilggende gedachte. diat rechtsvorming in earste instantle de taak is wan de polltilek en nlet van de rechter, dan is het zaak na te denken over mogell Jkheden om de rechter IIjke vrljheld terug te dringen Inzoverre dle het gevolg is wan gebreken wan ons staatsbestel. Dit is m.l. des te noodzakelljker. "nu de de Hoge Raad zloh aanvankelljk nog met de dekmantel van de anticlperende antlclpatle, met name in de Jaren tachtilg steeds meer de rol van wetgever is gaan aanmeten. Ik denk nier met name aan thet zogenaamde Stlerkalf-arrest (HR 7-3-1980, NJ 1980, 353), het arrest Boon-Van Loon (HR 27-11-1981, NJ 1982, 503) en de bekende arresten in zake de ouderll Jke macht en voogdIJ over Kinderen na echtschelding en samenwoning (HR 21-3-1986, NJ 1986, no. 585, 586, 587, 588). Ging de Hoge Raad in het Stlerkalf-arrest nog betrekkell Jk plompwer loren om, zich legltimerend met een beroep op het NBW, blJ Boon-Van Loon blljkt de Hoge Raad zlch duldelljk meer bewust geworden van zlin quasl-wetgewende activitelt, want de Hoge Raad bouwt en soort overgangsrecht in alsof $\infty$ die datum van de ultsprak een nleuwe wet van kracht is geworden. In het geval vam de ultsoraken over de ouderlluke macht en voogdl] van 1986 kon de Hoge Raad $z$ ich beroepen op het Europees Verdrag voor de Rechten van de Mens, maar het unleke erwan is toch wel, dat de Hoge Raad in een meer omvattende reglelling woorzlet ter vulling van de regellingslacune, dle ontstaan was als gevolg van het felt dat de wetgever zlch kennel/jk nlet bewust was geweest van de strijld wan artikel $161 \mathrm{BW}$ met net Europese Verdrag. Dergellike ultspraken roepen envoldllg om bezinning over de rechterlilke w IJheld en verantwoordell.jkhold; zoals dan coke al in een recent proefsch ift Is geschlled (68).

zillun afgezlen van Internatlonalle verdragen een aant l boven reeds genoemde redenen waarom de rechter steeds vaker gedwongen is om rechtsvormena op te treden in kwwestles die elgenllJk polltileke dellberatle zouden vereisen, hetzII omdat er onvoldoende grondsiag in de wet is waarbll de Hoge Raad kan aanknopen, hetzlI omdat de 


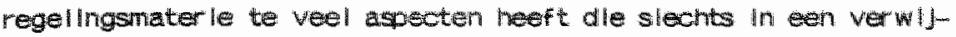
derd verband staan net de blj de rechter voorllggende zakk. Bowen is cok al hot nodlige gezegol over het slectit functloneren var de

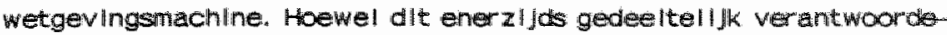
$11 \mathrm{Jk}$ is voor de boenemende rochter lljke wheld, trest or anderzljos ook een stimulerend ef fect oo als gevolg van de wiljheld alle de rechter $z$ lon permittert. De wetgever meent allicht zhich minder druk te hoeven maken over de kwalltelt van de wet omdat de rechlor als het al te gek wordt wel zal ingrljoen. Op die manler drelgt een verschulving in staatsrechtelljke verantwoordelljkheden op te treden dle nlet goed past in ons politlek systeem.

Tot slot van deze openibare les wll lk daarom een voorstel doen dat ef nlet alleen gerloht is te komen tot een zeker herstel van de verdelling van de verantwoordelljkheden tussen wetgever en rechter. maar dat tevens de wlsselwerking tussen rechtsogmatlek en wetgeving wil stimuleren en wei in de rlohting wan een sterkere mate wan verwetenschapoelliking van belde. Het voorstel dlat hiler gedaan zal worden is overlgens daarmee alleen nlet kracht lg genoeg te motive ren, aangezien het een mogal Ingr/jpend gevolgen heeft voor het politleke bestel. Daaron duld ik in het kort ook andere gebreken in ons polltleke bestel aan, dle mulus inzlens door mijn voorstel eveneens zouden kunnen worden bestreden:

1 Van duallisme in ons staatsbestel is weinlg meer over: reger ling en ambtenaren hebben een tamelljk verstikkende grees ( $v$ la regeeracooorden, drelgen met coalitlewbreuk en fractle-dwangl op de regeringspartllem, terwlJl de oppositle tot vooral op publicitelt gericht gekrabbel in de marge veroordeeld is. De polltlek wordt gemaakt door een oligarchle van ministers, hoge ambtenaren, minlsters, fractlelelders en de grote georganlseerde belangengroepen. De elgen werantwoondell ikheld van mlnisters en parlementsleden stelt welinlg voor (69).

2 Pollticl hebben onvoldoende aandacht woor wetgeving, In het bilzonder voor zover die polltlek viet interessant is en laten vla kaderwetgeving en vage normen weel te veel over aan de ultvoerende macht.

3 Blj politicl bestaat flet alleen en gebrek aan belangstelling 
maar ook eer groot gebrek aan deskund lgheld op het terreln wan de wetgeving.

4. Aangezlen polttiol mottem in betrekkellk veel tljd aan wetgeving moeten besteden, hebben ze minder tljd over voor hun andere taken, het bepalen van het beleld voorzover dat los staat wan de wetgewing en de controle oo de uitvoerende macht. Dat er met name op dat latste pumt het nodige aan schort, hebben de schandalen beginnend met de Lockheed-kwestle toch wel duldell Jk gematakt.

MIIn vocrstel luldt nu als volgt. De Eerste Kamer wordt omgevorma tot en ultslultend wetgevende kamer met ultzonder ing van de begrotingswetgew ling. De Tweede Kamer verlllest in pr Incilpe het recht wan amendement en concentreert zich op beleid en controle. Niettemin houdt de Tweede Kamer greep op het totale overheldsgebeuren niet alleen doordat ze de allgemene polltleke en financliele llinen ultzet ook voor de wetgevling, maar ook doordat ze een in de Eerste Kamer aangenomen wet kan werwerpen blnnen een bepaa lde termun na aaneming erwan in de Eerste Kamer. In geval van werwerping zou In mijn voorstel echier de verpllchting ontstaan, dat het door de Tweede Kamer verworpen wetsontwerp blnnen een vilJ korte temill in verenigde kamers opnleuw in verkorte procedure in behandelling wordt genomen. Wordt dle termlln niet gehald, dan vervalt de rechtsm geidigheld van net verwerplngsbeslult. De Eerste Kamer heeft het recht van InItlatlef, terwljl de Hoge Raad, daartoe eventueel gestimuleerd na tussenkomst van de Procureur-general via cassathe In het belang wain het recht $(70)$, verzoeken tot rechtsherwor$\mathrm{mlng}$ kan Indteruen, In dringende gevallen vergezeld van een aankondiging over hoe de Hoge Raad zich voorstelt te gaan besilssen, Indlen de Eerste Kamer nlet bereld is het werzoek op redelljke termlin in behandeling te nemen. Eljkomende voorstellen zllu:

1 De Raad van state wordt als adviseur voor de wetgeving afigeschaft.

2 De Tweedie Kamer worden gekozen in een districtenstelsel (71).

3. De HR wordt In het belang van de machtenschelding en van de rechtseenheld cassatle-instantle voor alle nlet-adminlstratlleve recintsgangen. 
MIIns inzlens heeft dit woorstell de volgende voordelen:

1 Verhoging van de deskundigheld in het par lement doon speciallswtle naar functle verdeeld ower de twee Kamers. De wetgevende kamer zal alleen maar aantrekkelljk zunn voor mensen met speolfleke deskundigheld op thet terreln wan wetgevlng on in inder aaintrekkelljk voor lleden dle wooral in beleld geinter essevid zijn. Dle zullen veel beter terecht kunnen in de Tweede Kamer. De Tweede Kamer zal zlch vooral kunnen concentreren oo het uitzetten var de grote polltleke lljnen en de ultoefening van en effectlevere controle op thet overheldsbeleld.

2 Doordat de uteindell Jke verantwoordell Jkheld voor wetgeving bil de Tweede Kamer, respectllevelljk cie Verenlgde Kamers berust zal het ministerible 'onaanvadrabaar' in de Eerste Kamer minder gewort krljgen. Partijawang in de Eerste Kamer zal hlerdoor minder gemakkellyk uitgeoefend kunnen worder, met name als de leden van de Tweede Kamer oo distr lictsbas Is verkozen worden, waardoor ze minder afhankelijk worden van de partljbazen. De Tweede Kamer zal zlch moeten hoeden al te vaak in de Eerste Kamer aangenomen wetsontwerpen te verwerpen, omdat het dan onmogelifk wordt de termilun voor herbehandelling te halen.

3 Het aldus bewerkstelligde therstel van dualisme in de polltilek zall deze interessanter maken, meer belmwloed ingsmogell jkheden aan de klezer bleden onder andere vla het distrllctenstelsel, volgens hetwelk de Tweedie Kamer gekozen wordt. Het verdlent over lgens geen aambeveling dit stelsel cok te hanteren voor de Eerste Kamer, aangezlen dan de kans op minder deskumdige leden groter wordt.

4 Het parlement zal nlet meer oo de willze a is dat tot nu toe het geval is geweest de polttlek verantwoordellikheld voor " vrlje rechtsworm Ing" op de rechter kunnen afschulven. Doordat de Hoge Raad aankondlgt, dat bepaalde kwestles geregeld dlenen te worden en hoe hij zich voorsteit te beslissen Indlen een regelling ullt-

- blifft, is thet parlement exollclet verantwoordelljk voor een eventueel gebrek aan inltiatlef aan besluitvaardigheld. Omgekeerd kan van die rechterlilke macht vierwacht worden, dat ze zich van rechtswormende actilwitelten onthoudt, die geen basis in het 
geldende recht vinot, en dat ze zlch gebonden achten aan gevesthgote preconten zolang nlet aangekondlgd is, dat de Hoge Raad zal omgan blj ultolljwer van een door het parlement te scheppen regelImigl. Overlgens kan het par lement natuur II jk wel goede redenen hebben on de rechtsvorming aan die rechter over te laten, namelijk daar war her on simpele of oncontroversiele zaken gaat of waar zonder ontwikeling van casuTstlek geen z lnwolle wetgeving mogelljk ls. in het door mlJ woorgestelde systeem, waar in de wetgewer vooraf de kans krljgt on een regelling te makem, wordt de schiln wermeden, dat de rechter alleen maar het geldend recht: toepast, zodat anders dan nu, achteraf Ingrl jpen door de wetgewer naar aanlelding van de rechtspraak nlet kan worden cogevat als een veroordelling ervan (als rechtstoepassing).

5 De Rad van state kan als adviseur bll wetgevingswragen worden afgeschaft, alangenomen dat de Eerste Kamer voorzlen wordt vain voldoende assistentle. Nlet alleen blljken de adviezen van de Raad van state een beperkte Invloed ult te oefenen, maar ais ze Invloed hebben, is dit meestal het geval op grond van polltieke In op grond van Jurldische overwegingen (72). De Raad van state Is lin wezen een resldu van midde leuwse, ollgarchlsche vorm van besturen. Dat deze tot een ongewenste mengeling van polltiek en wetenschappellijk gezag kan lelden, Is ampel gedemonstreerd in de krullswluchtwapenkwestle. Gegeven een op wetgeving gespecialt seerde kamer is aannemellJk dat daar op zl.Jn minst evenveel deskundigheld op het terrein van wetgewing geconcentreerd zal zl.Jn als thans bil de Read van State.

6 Door deze Inst/tutionalisering van de wetgevingsfunctle zal de aandacht van rechtsgeleerden in belangrlJk mate van rechtspraak naar wetgewing kunnen verschulven en zal en vruchtbare wlsselwerking tussen wetgeving, rechtspraak en rechtsdogmat lek co gang kunnen komen.

IK ben mIJ ervan bewust dat mIIn voorstel mede gernsplreerd is door giehechtheld aran oud-I lbera le beglnselen. De ultholling van de Indlviduele verantwoordelljkheld van $\mathrm{m}$ inisters en par lementsleden staat mil evenzeer tegen als een concentratle wan polltieke macht blj 
rechters. Wat mll betreft mogen ministers meer co wethouders en par lementarlers meer op gemeenteraadsleden IIJken, ter wII rechters geen rechtsorake is mogen $z$ IIn. Ongetw IJfeld heeft mIIn voorkeur ook te maken met een pragmat lsche visle op polltiek. Ik kan nlet inzlen waarom de visle op defensle nocdzakellyk samenhangt met dle op de economische polltlek "op onderwljspolitlek enz." hoewel natuluIIJk wel raakwlakken zullen zIIn tussen de versehlllende minlstio rles met name in de sociall-economische dr lehoek. Een overmatige Ideologisering van polltleke kwestles is een donterlhaald restidu van de perlode vain tegenstellingen wan confessles en soclale kllassen. die hun huldige betekenis voornamelijk ontlenen aan het felt dat ze geTnst/tutional Iseerd $z$ IJn in de staats- en rechitsorde. 

Noten.

1. Eerder overkwam mil dat bl』 'Jurlsterl] ln Nederland', Deventer 1981 en 'Grondwet en Krulsvluchtwapers', Assen/Maastr loht 1986. Belde boeken waren in corsprong bedoeld alls artikelen. Ik ben kennelljk volstrekt ongeschlkt woor een unlversalr systeem systeem waarin alles in tljd en man/wrouwhracht tot een maand nauwkeurig gepland moet worden, het Taylor-system van Deetman en co., fabrikanten van bedrukt papler te "s-Gravenhage.

2. Zoals G.E. Van Maanen blJvoorbeeld oo ontmythologiserende wilze gedaan heeft in $z$ In proefschrlft "Onrechtmatlge Daad", Deventer 1986.

3. Zo constateert bljwoorbeeld J. Griffiths in "Een toeschouwersperspectlef op de euthanasle discussle:, NJB 1987, p. 681 e.v.

4. Zie noot 1. Dle stelling is nader onderbouwd in miln artikel 'Paradoxen en aporleen van constitutionele rechtsregels' in: J.H.M. Klanderman en N.H.M. Roos (red.), Interne en externe analyses van recht, Z wolle 1987.

5. Aan de conclusles ult rechtstheoret ische over wegingen kunnen over Igens wel degelljk normatleve conclusles verbonden worden, terw IJl de rechtsfllosofle zeer wel kan aanknopen blj logische en structuurtheoret lsche kenmerken van recht. De kentheorle van het recht vormt de verblndende schakel tussen rechtstheor le en rechtsf Ilosofie.

6. Men zle hlervoor: L. Boon, De List der Wetenschap, var latle en selectle: voorultgang zonder rationallteit, Baarn 1983.

7. Men zle ter lllustratle hlervan: S. Macauley, Non-Contractual Relations in Business, in: 28 Amerlcan Soclologlcall Revlew (1963), p. 55-66.

8. Verwetenschappelljking wan het recht $11 \mathrm{jkt}$ gebonden aan twee noodzakelijke, maar geenszins voldoende voorwaarden: onafhankelljkheld van de staat en de afwezlgheld van al te onmlddellljke betrokkenheld blj de rechtspraktljk van een aanzlenlluke groep van primali academlsch georlienteerde rechtsgeleerden. Die voorwaarden zilln cloor de aard van het vak elgenlljk maar zelden gegeven geweest (Rome; MIddeleeuwse rechtsscholen, de Dultse rechtsleer in de negentlende eeuw). Blikomende voorwaarden ziln gelegen in de positle van de Jurlsten als stand en hun Invloed en afhankelljkheld wan de rechtsscholen, alsmede de onafharikelljkheld van deze liatsten ten opzlchte van de staat.

9. Men zle daarvoor bljvoorbeeld: M.S. Larson. The Rise of Prom fessionallsm: A Soclological Analysis, Berkeley 1977; Max We ber, Wrtschaft und Gesellschaft, Tublngen 1922, p. 508 e.v. Weber zag de 'Frelrechtsschule' vooral als een merkwaardige verblnding van conservatleve standsbelangen en soclalistische revolte tegen het 'Ideologisch' geachte formalisme van het privaatrecht. I $k$ heb hlerover geschrewen in "Antlformale Tendenzen Im modernen Riecht - elne These Max Webers, diskutlert am Belsolel der Lalenrichterfrage, opgenomen in: S. Breuer $/ H$. Trelber (Hrsg.), Zur Rechtssozlologle Max Webers, Interpreta- 
thon; Krtik, Welterentwloking, Opladen 1904.

10 . Zo blyoorbeld MBM. Vranken, Het Now en de twee soorten Intoeringsoljn, $\mathrm{NJB}$ 1986, p. 1242 .

11. J.M. van Dunhe, Mar eer spoedige invoering van het nleuwe bw? Llever snel recht dan goed recht, NJB $1904, p_{n} 669$ e.w.

12. A. PItlio. Het Erfrecht in het Ontwerp-Mellers RMT 1964, P. 463 e. $\%$.

13. K.F. von Sawligy, Vom Eeruf unsere zelt fur Gesetzgebung und

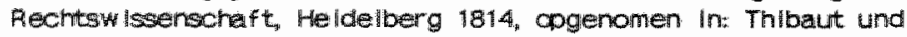
Savlgny, Monchen 1973 .

14. Mers zle A. Pltlo, Een voor de praktiljk van het rechtsleven hachell Jke ondermeming, in: Falt accomoll. Zwolle 1983, 0. 3 e.v" men zle ock de "repllek" van de haind van R.S. Melyer, Een ger chtvaardigde verrljking, $0.0 .$, p. 17 e.v.

15. Men zle 0.2.: J. van Dunne, waar doet het plJn?, Advocatenblad 1987, p. 125 e.w.

16. Men zle $c$. Groenendljk, Bundeling van belangen blj de burgerlljke rechter, Zwolle 1981.

17. Zll M. Galanter, Why the have's come out ahead, Law and Soclety Rewlew, 1974-75, p. 95 .v.

18. H,C.F. Schoordilk, Paul Scholten, Meljers en de (her)codifilcatlegedachte. WPNR 5314 (1975; Scholtenmummer), p. 572.

19. Men zle bl woorbeeld Van Dunne, o.c.

20. Over de verhoudling van rechtszekerheld en rechtsontwikkelling heb IK geschreven In de eerder geclteerde beschouwing over Max Weber. Ook Weber had onvoldoende In de gaten, dat de functle wan speclalisatle in sociale controle, c.a. een gespeciallseerde rechtstal, nlet dlent te verminder ing van de onzekerheld In geval wan een authentlek rechtsconflict, maar Julst de vergroting var het aantal mogelljke constructles van besilssingen.

21. Dok Schoordljk heeft in ziln in noot 18 genoemde publlcatle bliggedragen tot een nuancer Ing van het beeld wan de standounten pro en contra hercodiflcatle van voor de oor log.

22. K. Wlersma, Mellers en de heroodiflcatle, WPNR 5504 (1980), p. 22 e.v.

23. Men zle in dit verband ook noot 59.

24. J.C. van Oven, Mlel jers voor het professoraat. RMT 1950, p. 110.

25. R.P. CleverInga, Herdenking van Eduard Maum ls MelJers, RMT $1954, \mathrm{P}, 282$.

26. E.M. Meljers, Verzamelde privaatrechtell lkke opstellen, Lelden 1954 , p. 22 e. $v_{\text {; }}$ voor dergelljke ultlatingen zle men ook 'WIJzlglingen en aanvillingen van het Burgerlljk wetboek na 1838'. Meljers bljdrage can het Gedenkboek EW van 1838, cogenomen in de verzamelde opstellen. p. 109 e.v., H.h.b. p. 134.

27. Van belang in dit verband is de valgende ultspraak van Kisch In: J. M. valn bunne e.a., Acht clvillsten in burger, Zwolle 1977, p. 12\%. Klsch, die twee Jaar met Meljers In Westerbork en Theresilanstadt gevangen hest gezeten; zegt: 'Ook herininer Ik: me dat hiJ herhaldelijk verklaarde, dat hil zloh in wezen als misiukt beschouwde: hlj had polltiek en leglsletlef werk willen presteren, maar de Nederlandsse over hell had hem daartoe geen kans gebodlen, en "dat was dan misschien wel de wetenschep ten goede gekomen", maal" het had hem verstoken van de functies dle hill bovenal begeerde".

28. Zle miln bljarage over Van vollentoven In: T.J. Veen en P.C. Koo, Zestig Jurlsten, Zwolle 1987. 


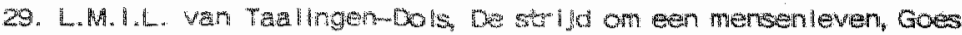
1900, 0. 205. Van Eysinga, asm groot bewonderagr van -Van Vallenhowen, was tlluens de or tog kennelluk ook in de weer met de Groot blukens zin in loss verswhen boek 'Hulgh de Groot: "Haarlem 1945.

30. J.Th. de Smldt Codlficatle en Grotus, in: J. wan Dunne e.t.. Na oorlog en vrede, Arntem 1984, $\mathrm{b} .9$. e.

31. G. Oly, Over het behoud van het zakerifert. WPN 5694 (1984), p. 246 e.w. 2il hecht owerlgens een meer dath slechts opoervlakklge betekens aan Meljers "atarsulting" bij de Groot, namelljk de representatie in de terminologle van het recht van de soclaal-econom ische machisverhouding. Haar batoog van ale strekking komt mill niet erg overtulgend woor.

32. H.J.M. Boukema, Meljers en Solnoza, WPNR 5459 (197\%), o. it e.v. Uit andere bron heb lik wermomen, dat Meljers in Theresienstadt belangstelling zou hebluen genad voor Lelbnlz. die veel Invloed ondergaan heeft van Splnota"s gedachten. Belangstelling voor Splnoza en Leibniz past bll Meljers fascinatle door wiskunde en systematlek. Woigens miljn zegsman zou Meljers zelfs beteken Is gehecht hebben aan numerologle.

33. G.E. Langemeljer, Meljers en de rechtsdogmatlek. AMT 1950, D. 133 e.V.; Idem, besoreking van 'De Algemeene Begriboen'. RMT 1958 , p. 589 e.v.

34. H. Dolon, Scholten en Meijers: en tegenstellng?, WPNR 5314. p. 520 e.v.

35. P. Scholter, Algemeen Deel, Zwolle 1954, p. 54.

36. Bovendien zal men moeten opmerker, dat het beeld van het $19 e-$ eeuwse Jurlalsch denken in Nederland als extreern leglstisch, op zloinzelf al een karkatulur is, zoals P.C kop in Leglime en prlvaatrecht", Zwolle 1905 , en G.E. van Mazinen in "Onreohtmatlge daad" Deventer 1986, hebben laten $z$ len.

37. Zle noot 27.

38. Men zle Meljers' Verzamelde prlvatrechtell Jke opstellen, O.c. p. 133.

39. 0.C., p. 219.

40. Oo de blbllotheek van het ministerle van Justitle kan nog een spoor van deze affalre worden aangetroffen. Op de fliche in de kaartenbak is bll "Veegens-Oppenhelm" na de vermelding van 'Pitlo' in typeletters toegewogd:: "lees: C.H.F". Polak".

41. O.C., P. 120 .

42. P. Abas, Beperkende werk ling van de goede trouw, Deventer 1972, p. 47. men zle over de Inleldende tltel ook: J. Pel, De Inleldende Titel van het $\mathbb{N B W}$. Ars Aequi 35 (1986), p. 733 e.v.

43. Men zle: Acht clwlisten in burger, 0.c. p. 135.

44. O.C., p. 224.

46. Het historlsch verband tussen het ontwerp en de algemene begrippen is overlgens miet nelemal duldellik. Zodis eerder vermeld, beweert Clever Inga verwl Izend naar Wan Oven, dat Meljers al in ziljn Amsterdamse ti.jd aantekenlingen gemaakt zou helbben voor een NBW. Van Oven "meent" zllch dit te her Inneren, maar vond het kennell jk nlet nodig deze her lminer Ing bl] Mell Jers te verlfiteren, zodat lk dle her Innerlng weinlg vertrouw. Dat Meljers al ver voor de oorlog weel belangstelling had voor hercodiflcatle, is natuurlijk algemeen bekend en bllfkt ut diverse gescirlften. of hlj er toen ook al aan gewerkt heeft is overigens nlet bekend. Voor de bewering dat hll al tljdens de oorllog gewerkt zou hebben aar tekster voor een NBW theb IK maar een aarw ljzing kunnem winden. In het boek van mevrouw van 


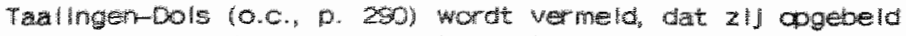

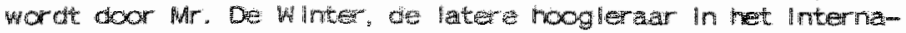
thonal prlwatrech te Amsterdan, dle als koerler wan de hoodse Raad optrad hussen Westerbork en Amsterdam. Deze deeft hedar mee viak woor Meljers' deportatle wan hem werk 'dat handelt over oen nleuw Bw te heboen ontvanger. IK heb niet

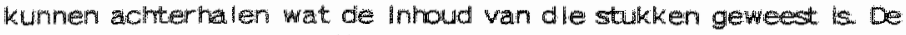
winters"zoon, mujn collega A.E. de whter, neeft mlj gezegd dat zun vader de van Meljers ontwangen stukken waarschlin Ifjk wee doorgegeven had aan Begstem. I l heb moelte gedaan om worr Inlliht ingen hiteromtrent met gregstelns zoon Phllo, dile in Frankrljk woonachtlg is, in contact te komen, maar dat is me tot nu toe nlet gelukt. Van Durne maakt melling van magelljke Invioed van ontwerpen alle Mel Jers reeds voor de oorlog vervaardigd heeft in ancler verband. HIl baseert zlch daarvoor $\infty$ inllloht lingen van de huldige noogleraar Roodmbe Boer die tussen 1949-1051 als secretaresse is opgetreden voor Meljers. Zlil moest, zo heft zlj $\mathrm{mll}$ beves tlgd, op cen gegeven moment teksten uittlkken dle moellikk leesbatar waren doordat de inkt sterk verbleekt was. Mellers vertelde haar dat dle teksten van woor de oorllog waren. Wolgens Van Dunne zlun dat vermoedelijk teksten dle Meljers gemaakt heeft in het kader van de uniflcathe wan het prlvatrecht (Unlarolt), dle, zo van Dunne, slechts blj ultzondering tot verdragen geleld hebben dle in werking getreden zi:Jn.

46. In ziln van grote waardering en wilendschap getulgende herdenklingsrode "Herdlenking wan Paul Scholten", gepublliceerd In het Jaarboek 1947-48 van de KNAW, opgenomen in WPNR nr. 5314 (1975), p. 471 e.v. zegt Meljers over Scholtens rechtsfllosofische gedachten: 'Veel in deze ulteenzettingen van Scholten is meer het belljden van een overkulging dan een streng wetenschappell.jk betoog' (p. 475).

47. P. van Schllifgaarde, Besprek lng van J.M. van Qunne, Normatleve ultileg van rechtshandelingen, RMT 1976, D. 546 e.v.

48. J.H. Nileuwentuls, Drle beginselen wan contractenrecht, Deverter 1979 , p. 14 e. $v_{\text {. }}$

49. J.M. van Dunne, Waar doet het pljn?, Advocatenblad 1987, p. 129.

50. I $k$ moet van Dunne om enlig geduld wragen voor een nadere motlwering van miln stelling. De verantwoording van zijn systematlek op dit punt geeft Meljers in ziln op pagina 277 vain de "Algemene begr lppen".

51. A. F. Bloembergen, Over de methode Meljers, WPNR 5504 (1980; Mel Jers-nummetr), p. $4 \pi$ e.v. De bljdrage wan Bloenbergen onderscheldt zlch van die van anderen, doordat his wat meer Ingat of Mellers opvattingen over blillikheld en over belangenafwegling.

52. D.J. Veegens, Een herwarder ling van Mel Jers, Lugdurum Batavorum Iur| Sacrum, Deventer 1982, D. 199 e.v.

53. Andere overwegingen in MelJers' geschr if ten over hercodif icatle aangevoerd, zijn het felt dat rechters het instrumentar lum missen om regel ingsikwest les dle boven een concreet geval ultgaan adecuaat te onderzoekem, laat staan dat zlJ zlloh in thet algemeen 0 wetgevende wijze zouden kunnen ultaten over hele klassen van gevallen in hun volledige complexltelt; de soms chaot lsche versnipper ling van burgerllik recht, de thoe langer hoe meer toenemende last van Jur lsprudentle le sllingerplanten in het krakkemlkklig gebouwde BW, dat nlet voorzlet in allerlei 
moderne rechtsiguren en allerle kwestles ongeregeld latat, die slechts incldented en min of nee toewallig in de rechtsorak aan de onde komen. omdat de rechtoraktljk met een grote boog ombeenloopt ult angst woor processen.

54. Langeneljer, 0.c. $1968, p$. 590. Langemeijer soreekt in dit verband Wan Meljers' 20 'weinlg nardrukkel llke sch llf w IJze". Wat Langemeljer daarmee bedoelt is mil nlet duldellyk, tenzly hil gewoon wil zeggen: compact zonder vel omhaal van woorden. Dit is echter geenszlins een probleem, zolang het abstractlia. miveau van het betoog relatlef latag bllft, zoals in de meste van Meljersi nechtsciogmatische geschriften. Zijn methodolow g) Ische geschlfften vragen echter Inderdaad een hoge mate van concentratle.

55. Langemeller, 0.1., 1958, p. 591.

56. Men zle daarover: J.H.M. Klanderman, Ratlo, wetenschap en recht, Zwolle 1986.

57. J. Eggens, lets over de ontwlkkellng van het pr waatrechtellik denken in de laatste halve euw, oratle Batavla 1935. Hoewel hll Scholten duldelljk bewondert, vindt hlj dat dlens. opvattingen nog teveel doen "denken aan de materlallstische meening, dat het recht ergens kant en klaar te vinden zou

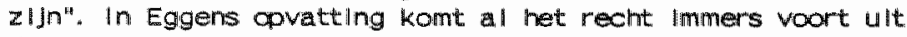
de ene rechtsidee, die zlch dllectisch-listor isch ontw Ikkeld. Scholtens existentlailstische ldee wan wezen IIjk onverzoen IIJke hoogste rechtsbeglinselen, sorak hem duldelluk nlet aan.

58. Men zle 0.a. W. Rosenbaum, Naturrecht und positives Recht, Neuwled 1972 .

59. In dit verband is het cok nuttlg te wiJzen oo het felt, dat Meljers in zlin "Herdenkung van Paul Schoiten", $0 . C_{\text {., }}$ D. $475_{\text {, }}$ zegt: "Nlets hinderde hem (Scholten) meer dan de slappe houding van de meeste zi Jner Amsterdamse collega"s'. Die comerking zal ongetw lffeld kwaad bloed gezet hebben in Amsterdam.

BO. In zijn terugbllk op "Norm en Handeling" In: Rechtsfllosof le en Rechtstheorle, 1984, nr. 3, p. 229 e.W. gaat Glastra van Loon helaas nlet in op de kwestle van de receptie van zlin proefson lft.

61. In "ludex vlator", Ars Aequl, 1967, p. 15, blllkt zelfs van insplratle varult de moderne katholleke Kerkleer, waar in volgens Ter Helde "soortgellyke trends te bespeuren (zljn) als in de algemene rechtsleer'. De functlonele rechtsleer maakt Inderdaad een in de Grlekse zin van het woord 'katholleke' indruk. overigens ook in die $z$ lin dat Ter Helde zlch op en nogal autoritalre manler beroept on wat 'de" moderne fllosofische antropologle zou leren, opvattingen die destijots al hoogst discutabel waren en wele daarvan IIggen thans te vergaan op de vull$\mathrm{nllshop}$ wan de ldengeschledenlis.

6. Men zle daarvoor miln bijdrage ower Schalten in: T.J. Veen en P.C. Keo, Zestig Jur listen, Zwolle 1987. p. 249.

63. Nota bene te Lelden, waar Glastra van Loon tot 19711 hoogleraar was geweest.

64. Men zile. E. Wan Alphen, Nleuwenhuls' theorle van het contracteren, een kr/tilek, Recht en kritlek 1986/1. p. 43 c.V. Howew Ik het met Valn Alphen eens ben, dat de aanslultng blj de taalthandelingstheor le door Nleuwenhuls welnig overtulgend is, meen Ik dat dit aan de elgenlljke analyse wan de arle beginselen weinig afdoet.

65. Deze heeft namelllk uitslultend een lwurlst lsche betekenis; en berust oo het triwlale concept van een vaag begrlo. Wlarda suggereart bowendien ten onrechte, dat vage begrippen altilja 


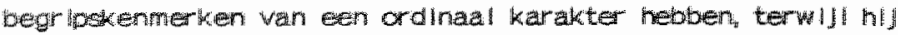
ook niet ingat op de declsieproblematlek in het geval vam meer dimensionele schenten.

B6. E.M.P. Mackaty; Economics of Information and Law, Montreal 1980.

B7. Men zle bv. J.T.K. Bos, stelselmatige rechtopraak, Zwolle 1986; en J.H.M. Klandeman en N.H.M. Roos (red, ), interne en externe analyses van rechti, Zwolle 1987 .

68. P.J.B. Kottenheglen, Vain precedent tot precedent, Arnhem 1986.

Dit zeer boelende promfschrlft is gescrewen onder lelding van Van Dunne, dle daarmese duldelljk laat zlen dat hlj ondanks zlun opoositle tegem het NBW, wel degelljk het belang van de onderschelding vam rechter lijke en regelgewende actwitelten in te zlen. Kottenhagens af $1 / \mathrm{J}$ ing van 'prosective overulling' oo grond van de doo' hem aangehangen 'Fallnormtheorle', kan $\mid k$ bl] gebrek aan appoclatle voor deze laatste echter nlet delen.

69. Ik her Inner in dit verband bljwoorbeeld aan de affalre-Van Aardemne, waarvoor Joekes bestraft werd en - gelukklg - vervolgens een amende honorable' tobedeeld kreeg van de klezers.

70. Daarmee bedoel $k \mathrm{k}$ een nlet aan en actuele of concrete casus gebonden vorm van cassatle, vaardoor de HR gelegenteld zou kflldgen zlch ult te laten op en wljze die thans nog steeds bekend staat als "oblter dictum".

71. Een voorstel tot verbetering vain het functloneren van het parlement oo het gebled wan de wetgewing is onlangs gedaan doon milun collega's Cohen en Bakker ('De Wetgever tussen Recht en Polltlek", Namens Jaargang 2 af (, 2, pag. 97w102). In hun voorstell wordt ochter een zware wissell getrokken op de Raad van State, een mijns inzlens ondemocratisch linst/tutt. ze hanteren een mIJns inzlens watk moellijk vol te houden onderscheld tussen techn isch-Jurldische en politleke kwestles. Nllet dat Ik zou menen dat Jurldische en polltleke kwestles meestal nliet redellJk god te scheiden $z \mid J n$, mar technlsche kwest les hebben soms belangrijke pol ltleke Implicatles en ongekeerd zodat het gevaar blijft dat de roll van de Raad van state onzuiver wordt. zoals a is ook het gew i was in de krulsvluchtwapenkwestle. Cok de coor Cohen en Rakker voorgestelde pracedure (verzoek om tweede advies door de Eerste Kamer aan de Raad van State, glevoligd door amender Ingsmogelljkheld blj positlef advies daartoe door de Raad van State en blJ aanneming, nader over leg tussen de kamers) IIJkt mlJ nllet al leen erg Ingew Ikkeld, maar er kan volgens mij cok nauwelljks een ingr Ijpende verbetering van het wetgevingsproces a Is geheel van verwacht worden. Hoe verdlenstellik de Eerste Kamer zilln werk thans ook doen mag, voor de meeste leden ervan blljft het een bijbaan naast de wele andere dle deze notabele pollticl vervullen.

72. Zle R.E. Bakker, De reactle van de regering en de Tweede Kamer op de wetgeversadviser Ing door de flaad van State. Regelmaat 1986, p. 125-128. 